\title{
Genomic Analysis of Limosilactobacillus fermentum ATCC 23271, a Potential Probiotic Strain with Anti-Candida Activity
}

\author{
Camilla I. dos Santos ${ }^{1}{ }^{\circledR}$, Carmem D. L. Campos ${ }^{2}{ }^{\circledR}$, Wallace R. Nunes-Neto ${ }^{1}$, Monique S. do Carmo ${ }^{3}$,
} Flávio A. B. Nogueira ${ }^{3}$, Rômulo M. Ferreira ${ }^{2}$, Ennio P. S. Costa ${ }^{1}$, Laoane F. Gonzaga ${ }^{2}$, Jéssica M. M. Araújo ${ }^{2}$, Joveliane M. Monteiro ${ }^{2}$, Cinara Regina A. V. Monteiro ${ }^{3}$, Fernanda S. Platner ${ }^{4,5}{ }^{\circ}$, Isabella F. S. Figueiredo ${ }^{4,5}$, Rodrigo A. Holanda ${ }^{2}$, Silvio G. Monteiro ${ }^{3}{ }^{(0)}$, Elizabeth S. Fernandes ${ }^{4,5}{ }^{(}$, Andrea S. Monteiro ${ }^{2}$ and Valério Monteiro-Neto $1,3, *$ (D)

Citation: dos Santos, C.I.; Campos, C.D.L.; Nunes-Neto, W.R.; do Carmo, M.S.; Nogueira, F.A.B.; Ferreira, R.M.; Costa, E.P.S.; Gonzaga, L.F.; Araújo,

J.M.M.; Monteiro, J.M.; et al. Genomic Analysis of Limosilactobacillus fermentum ATCC 23271, a Potential Probiotic Strain with Anti-Candida Activity. J. Fungi 2021, 7, 794. https://doi.org/10.3390/jof7100794

Academic Editor: Juliana

Campos Junqueira

Received: 21 August 2021

Accepted: 20 September 2021

Published: 24 September 2021

Publisher's Note: MDPI stays neutral with regard to jurisdictional claims in published maps and institutional affiliations.

Copyright: (c) 2021 by the authors Licensee MDPI, Basel, Switzerland. This article is an open access article distributed under the terms and conditions of the Creative Commons Attribution (CC BY) license (https:// creativecommons.org/licenses/by/ $4.0 /)$
1 Rede de Biodiversidade e Biotecnologia da Amazônia Legal, BIONORTE, São Luís 65055-310, MA, Brazil; camilla_itapary@hotmail.com (C.I.d.S.); wallaceneto2010@hotmail.com (W.R.N.-N.); enniocosta14@gmail.com (E.P.S.C.)

2 Laboratório de Microbiologia Aplicada, Universidade CEUMA, São Luís 65075-120, MA, Brazil; carmemcampos01@hotmail.com (C.D.L.C.); romulo.ferreira5@hotmail.com (R.M.F.); laoane_freitas@hotmail.com (L.F.G.); jessicamendesaraujo1@hotmail.com (J.M.M.A.); jovelianemello53@gmail.com (J.M.M.); rodrigo.holanda@ceuma.br (R.A.H.); andreasmont@gmail.com (A.S.M.)

3 Centro de Ciências Biológicas e da Saúde, Universidade Federal do Maranhão, São Luís 65080-805, MA, Brazil; carmo.monique@outlook.com (M.S.d.C.); augustofabn@gmail.com (F.A.B.N.); cinaraaragao@hotmail.com (C.R.A.V.M.); silvio.gm@ufma.br (S.G.M.)

4 Faculdades Pequeno Príncipe, FPP, Curitiba 80230-020, PR, Brazil; fsilvaplatner@gmail.com (F.S.P.); bellaafigueiredo@hotmail.com (I.F.S.F.); elizabeth.fernandes@pelepequenoprincipe.org.br (E.S.F.)

5 Instituto de Pesquisa Pelé Pequeno Príncipe, IPPPP, Curitiba 80250-060, PR, Brazil

* Correspondence: valerio.monteiro@ufma.br; Tel.: +55-98-3272-9591

Abstract: Limosilactobacillus fermentum (ATCC 23271) was originally isolated from the human intestine and has displayed antimicrobial activity, primarily against Candida species. Complete genome sequencing and comparative analyses were performed to elucidate the genetic basis underlying its probiotic potential. The ATCC 23271 genome was found to contain 2,193,335 bp, with 2123 protein-coding sequences. Phylogenetic analysis revealed that the ATCC 23271 strain shares 941 gene clusters with six other probiotic strains of L. fermentum. Putative genes known to confer probiotic properties have been identified in the genome, including genes related to adhesion, tolerance to acidic $\mathrm{pH}$ and bile salts, tolerance to oxidative stress, and metabolism and transport of sugars and other compounds. A search for bacteriocin genes revealed a sequence $48 \%$ similar to that of enterolysin A, a protein from Enterococcus faecalis. However, in vitro assays confirmed that the strain has inhibitory activity on the growth of Candida species and also interferes with their adhesion to HeLa cells. In silico analyses demonstrated a high probability of the protein with antimicrobial activity. Our data reveal the genome features of L. fermentum ATCC 23271, which may provide insight into its future use given the functional benefits, especially against Candida infections.

Keywords: probiotic; genomic characterization; Limosilactobacillus fermentum; Candida infection

\section{Introduction}

Candida species are considered commensal microorganisms in humans [1]. Nevertheless, they can cause opportunistic infections, including some that are less severe and superficially located, and others of a life-threatening systemic nature, particularly in immunocompromised patients. Localized candidiasis mainly affects the mucosa of the oral cavity and vagina [2,3].

Azoles are commonly used to treat candidiasis [4]. These drugs are fungistatic, meaning that an efficient immune system is necessary to control the infection and resolve its 
symptoms [5]. Other classes of antifungals may also be indicated, particularly when the etiologic agent is resistant to azoles, including nystatin, amphotericin B, flucytosine or echinocandins [6,7]. Thus, there is a need for new effective therapeutic approaches for candidiasis.

According to The International Scientific Association for Probiotics and Prebiotics, probiotics are defined as "live microorganisms that, when administered in adequate amounts, confer a health benefit to the host" [8]. A probiotic formulation can be administered as a single microorganism or in association with different species. In addition, probiotics may be mixed with prebiotics to enhance their benefits. For human use, a probiotic should preferably be of human origin, safe, and free of genetic vectors capable of transferring antibiotic resistance and/or virulence genes. They must have the ability to survive in adverse host conditions (such as acidic $\mathrm{pH}$, enzymes and bile acids) and to adhere to eukaryotic cells [9]. Probiotics can exhibit antagonism against microbial pathogens, stimulate the host immune system or confer other proven beneficial effects $[8,10]$.

Health benefits have been reported in both human clinical trials and animal studies. The benefits include the reduction of antibiotic-associated diarrhea and rotavirus diarrhea [11], preventive and adjuvant therapy in the treatment of certain cancer types [12-14], immunological modulation [15], improved response to vaccination [16], adjuvant action in the treatment of Helicobacter pylori infections [17], relief of irritable bowel syndrome [18] and treatment and prevention of allergies [19], in addition to preventing type 1 diabetes in animal models [20].

The benefits produced by probiotics may be related to their ability to regulate the microbiota through competition for adhesion sites, as well as the production of soluble compounds, which can also have immunomodulatory or antimicrobial effects [21]. The modulation of the immune system by probiotics can result in enhanced antibody-mediated responses, reduced inflammation and increased phagocytosis, in addition to several other responses [22,23].

Many genera of bacteria (and yeasts) have been proposed as probiotics, but the most commonly used are Lactobacillus and Bifidobacterium species [24,25]. Lactobacillus is the most complex genus among lactic acid bacteria (LAB) and represents a defined group of Grampositive, non-spore-forming rods or coccobacilli, which are fermentative, aerotolerant or anaerobic with a $\mathrm{G}+\mathrm{C}$ content usually below $50 \mathrm{~mol} \%$ [25]. The genus is included in the phylum Firmicutes and has recently been reclassified into 25 genera [26].

Lactobacillus fermentum has also undergone a change in its taxonomy, with its name being changed to Limosilactobacillus fermentum [26]. This species has been detected in human milk and feces, animal feces, plant tissues and dairy foods [27-34]. Some of the beneficial effects of this species, which are strain-specific, have already been described. These effects include reduction of cholesterol, prevention of community-acquired intestinal and upper respiratory infections, antioxidant potential, anti-aging action, anti-inflammatory activity, immune system stimulation and antimicrobial activity [27-30,32,33,35,36]. In our previous study, the L. fermentum ATCC 23271 strain, originally isolated from the human intestine, exhibited the capability to adhere to eukaryotic cells, mucin binding ability and inhibitory activities on the growth and cell adherence of genital pathogens, principally Candida species [37]. Thus, in order to gain further insight into the genetic basis of the probiotic potential of the L. fermentum ATCC 23271 strain, we sequenced its whole genome. We also compared its genome with the genomes of other L. fermentum strains in an attempt to identify its possible mechanisms of action.

\section{Materials and Methods}

\subsection{Bacterial Strains and Growth Conditions}

The following microorganisms were used in this study: L. fermentum ATCC 23271, enteroaggregative Escherichia coli (EAEC) 17.2, E. faecalis (ATCC 29212), Salmonella enterica subsp. enterica sorovar Enteritidis (ATCC 13076), C. albicans ATCC 90028, C. albicans SC 5314, Candida krusei ATCC 6258, C. parapsilosis ATCC 22019, C. albicans 44 (oral isolate), 
C. albicans CAS (vaginal isolate), C. krusei GJFD (vaginal isolate), C. parapsilosis FSG (oral isolate) and C. parapsilosis RCL (vaginal isolate). Probiotic properties were also evaluated against clinical Candida strains isolated from oral and vaginal cavities, belonging to the Culture Collection Sector of the Biology Laboratory of the Federal Institute of Education, Science and Technology of Maranhão. L. fermentum ATCC 23271 strains were cultivated in De Man, Rogosa, and Sharpe (MRS) agar and broth (Difco Laboratories, Detroit, MI, USA) under anaerobic conditions, while the other bacteria and yeasts were grown in brain heart infusion (BHI) agar/broth and Sabouraud agar, respectively (Difco Laboratories, Detroit, MI, USA), under aerobic conditions. All microorganisms were incubated at $37^{\circ} \mathrm{C}$ for $24 \mathrm{~h}$.

\subsection{Whole-Genome Sequencing of Limosilactobacillus fermentum ATCC 23271}

Genome sequencing of L. fermentum ATCC 23271 was performed by Neoprospecta using the Illumina HiSeq4000. Genomic DNA was extracted using the PureLink ${ }^{\circledR}$ Genomic DNA Mini Kit (Invitrogen, Carlsbad, CA, USA) according to the manufacturer's instructions. The complete genome was sequenced using the Illumina MiSeq paired library approach and prepared using the Nextera XT DNA Library Preparation Kit (Illumina, San Diego, CA, USA). The sequence readings were assembled using A5 software [38] and processed for adapter cutting, quality filtering and error correction to generate the contigs and scaffolds. In addition, CAP3 software [39] was used to improve the scaffolding assembly, cut low-quality regions and correct erroneous links between contigs. The pre-assembled genomic DNA sequences were annotated using the software tool Prokka [40].

\subsection{Genome Analysis}

The annotated sequences of the L. fermentum ATCC 23271 genome were analyzed using Rapid Annotation using Subsystem Technology (RAST) (available at https: / / rast. nmpdr.org/rast.cgi accessed on 10 January 2017). The Basic Local Alignment Search Tool (BLAST) was used to search for similarities in the protein databases of the National Center for Biotechnology Information (NCBI) and Universal Protein Resource. Phaster (https://phaster.ca/ accessed on 17 May 2021) was used to search for prophage-like clusters. Orthovenn (http:/ / probes.pw.usda.gov/OrthoVenn accessed on 17 may 2021) was used to search for orthologous proteins common to the lineages L. fermentum 2760, L. fermentum DR 9, L. fermentum 3872, L. fermentum CECT 5716 and L. fermentum AGR 1485 [41]. To search for genes associated with bacteriocins, the BAGEL4 program (available at http: / / bagel4.molgenrug.nl/ accessed on 23 June 2020) was used, and a protein with similarity to another known bacteriocin was first analyzed using the Signal P 5.0 Server to identify the signal peptide cleavage region. The mature protein sequence was analyzed in the CAMP database using four machine learning algorithms, including Support Vector Machine, Random Forest, Artificial Neural Network and Discriminant Analysis, to predict its antimicrobial activity [42]. A phylogenetic tree was generated using the nucleotide sequence using the TYGS server (http:/ / tygs.dsmz.de accessed on 3 February 2021) [43] using genomic sequences deposited in GenBank. To analyze evolutionary relationships between species, Mauve linked in Geneious software [44] was used. PathogenFinder v. 1.1 [45] was used to estimate the pathogenicity of the strain in human hosts. ResFinder v. 3.1 [46] and the Comprehensive Antibiotic Resistance Database (CARD) v. RGI 5.1.0, CARD 3.0.7 [47] were used to search for antimicrobial resistance genes. Virulence determinants were analyzed using VirulenceFinder v. 2.0 [48]. The rapid identification and annotation of prophage sequences within the genome of L. fermentum ATCC 23271 were performed using the phage search tool enhanced release (PHASTER) [49]. The CRISPR Finder tool was used to detect CRISPR direct repeats and spacers [50].

\subsection{Antagonism Assay}

Antagonism tests were performed using the overlay method [37]. L. fermentum ATCC 23271 grown on MRS agar was standardized at $\mathrm{OD}_{600 \mathrm{~nm}}=0.1$, in MRS broth, and then $5 \mu \mathrm{L}$ of the inoculum was spotted (about $0.9 \mathrm{~cm}$ ) on MRS agar (Difco Laboratories, Detroit, MI, 
USA) and incubated for $48 \mathrm{~h}$ under the same conditions. After that period, a $2 \mathrm{~mm}$ layer of Muller-Hinton agar (Difco Laboratories) was added onto MRS agar, and the standard pathogen inoculum $\left(1 \times 10^{8} \mathrm{CFU} / \mathrm{mL}\right)$ was seeded. Petri dishes were incubated at $37^{\circ} \mathrm{C}$ for $24 \mathrm{~h}$ under aerobic conditions, and subsequent zones of inhibition were measured.

\subsection{Interference on Cell Adhesion}

Cell adhesion experiments were performed was carried out with Candida spp. by using HeLa (ATCC CCL-2) cell line yeast, respectively [51], with minor modifications [37]. Cultivation was carried out in Dulbecco's Modified Eagle's Medium (DMEM, SigmaAldrich, Burlington, MA, USA) culture medium supplemented with 10\% fetal bovine serum (FBS, Sigma-Aldrich) and 1\% antibiotic and antimycotic solution, incubated in 5\% $\mathrm{CO}_{2}$, at $37^{\circ} \mathrm{C}$ in a humidity-controlled environment. The cells were seeded in 24-well plates at a concentration of $1 \times 10^{5}$ cells/well and left to reach $80-90 \%$ confluence. Then, the microorganisms were added at concentrations of $1 \times 10^{6}$ cells/well of pathogens and $1 \times 10^{8}$ cells/well of $L$. fermentum ATCC 23271. The tests were performed in three different ways: by adding the two microorganisms at the same time (competition): first L. fermentum ATCC 23271 for $1 \mathrm{~h}$ and then pathogens (exclusion), or first pathogens for $1 \mathrm{~h}$ followed by L. fermentum ATCC 23271 (displacement). The plates were incubated for $4 \mathrm{~h}$, and then dilution and plating were performed for CFU counts after incubation on Sabouraud agar.

\subsection{Tolerance to Gastrointestinal Conditions}

The tolerance of L. fermentum ATCC 23271 to acidic $\mathrm{pH}(\mathrm{pH}=2$ and 4$)$ and bile salts ( $0.5 \%$ and $1 \%$, Oxgall, Sigma-Aldrich) was verified as described by Monteiro et al. [52]. Initially, $900 \mu \mathrm{L}$ MRS (Difco Laboratories) was adjusted to $\mathrm{pH} 2$ or 4 or supplemented with $0.5 \%$ or $1 \%(w / v)$ Oxgall (Sigma-Aldrich). The medium without modifications was used as a control. An aliquot of $100 \mu \mathrm{L}$ of a $24 \mathrm{~h}$ culture of L. fermentum ATCC 23271, previously washed with PBS, was inoculated into tubes containing modified or unmodified MRS. After incubation at $37^{\circ} \mathrm{C}$ for $3 \mathrm{~h}$ under anaerobic conditions, the percentage of viable bacteria was calculated by counting CFUs on MRS agar (Difco Laboratories).

\subsection{Antibiotic Susceptibility Test}

Antibiotic susceptibility assays were performed using the modified agar diffusion method, using commercial discs (Thermo Scientific ${ }^{\mathrm{TM}}$ Oxoid $^{\mathrm{TM}}$ ) containing different antibiotics, including cefoxitin $(30 \mu \mathrm{g})$, cefazolin $(30 \mu \mathrm{g})$, chloramphenicol $(30 \mu \mathrm{g})$, ciprofloxacin $(5 \mu \mathrm{g})$, clindamycin $(2 \mu \mathrm{g})$, erythromycin $(15 \mu \mathrm{g})$, gentamicin $(120 \mu \mathrm{g})$, linezolid $(30 \mu \mathrm{g})$, nitrofurantoin $(300 \mu \mathrm{g})$, oxacillin $(1 \mu \mathrm{g})$, penicillin $\mathrm{g}(10 \mu \mathrm{g})$, rifampicin $(5 \mu \mathrm{g})$, sulfazotrim $(25 \mu \mathrm{g})$, tetracycline $(30 \mu \mathrm{g})$, tigecillin $(15 \mu \mathrm{g})$ and vancomycin $(30 \mu \mathrm{g})$. L. fermentum ATCC 23271 overnight culture $\left(37^{\circ} \mathrm{C}\right.$ in anaerobiosis) was standardized and inoculated on MRS agar medium, as previously described [53]. Subsequently, antimicrobial discs were placed, and the plates were incubated anaerobically at $37^{\circ} \mathrm{C}$ for $24 \mathrm{~h}$. The inhibition zone diameter of bacterial growth was measured (in $\mathrm{mm}$ ), and susceptibility was assessed according to Charteris et al. [53].

\subsection{Ethical Aspects}

Clinical microbial strains were obtained from a previous research project approved by the Ethics Committee of CEUMA University (N 2.519.446/2018/CEP-UNICEUMA).

\subsection{Statistical Analysis}

Data analysis was performed using GraphPad Prism Software 5.1 (GraphPad Software, San Diego, CA, USA). Student's $t$-tests were performed to assess differences in the adhesion assays when the Candida strains were assayed alone or in the presence of L. fermentum ATCC 23271. All experiments were performed in triplicate on three independent days, and statistical significance was set at $p<0.05$. 


\section{Results}

\subsection{General Genome Features and Comparative Analysis}

To search for the genetic basis of the probiotic properties of interest, the genome of $L$. fermentum ATCC 23271 was sequenced. The genome was deposited in the NCBI database under the BioProject accession number PRJNA729474. Raw reads were deposited in the Sequence Read Archive (SRA) under the accession number SRX10856814. The assembled genome sequence was deposited in DDBJ/ENA/GenBank under the accession number GenBank: JAHBRU000000000.1.

Preliminary annotation data for the L. fermentum ATCC 23271 genome are listed in Table 1. The genome contains 2123 protein-coding sequences (CDS).

Table 1. Characteristics of the assembly of L. fermentum ATCC 23271 genome.

\begin{tabular}{cc}
\hline Attribute * $^{*}$ & Indicators \\
\hline Genome size (bp) & $2,193,335$ \\
G + C content (\%) & 50.9 \\
N50 & 33,843 \\
L50 & 22 \\
Number of contigs (with PEGs) & 223 \\
Number of subsystems & 312 \\
Prophage-like clusters & 2 \\
CDS & 2387 \\
CDS (with proteins) & 2123 \\
$\mathrm{~N}^{\circ}$ of RNAs & 79 \\
$\mathrm{~N}^{\circ}$ of tmRNA operons & 1 \\
$\mathrm{~N}^{\circ}$ of tRNA & 55 \\
$\mathrm{~N}^{\circ}$ of rRNA & 21 \\
$\mathrm{~N}^{\circ}$ of CRISPR loci & 2 \\
\hline
\end{tabular}

\section{${ }^{*}$ Genome sequencing was performed using Illumina libraries designed using shotgun sequencing (Nextera)} Genome annotation was performed automatically using the PROKKA tool.

The RAST analysis showed the presence of 2123 coding sequences distributed in 312 subsystems, of which 1614 were related to non-hypothetical proteins and 509 to hypothetical proteins. These genes were found to be associated with several subsystems (Figure 1). Through image analysis, it was seen that the subsystems with the highest number of genes are related to the production of cofactors, vitamins, prosthetic groups, pigments, protein metabolism, amino acids and carbohydrates.

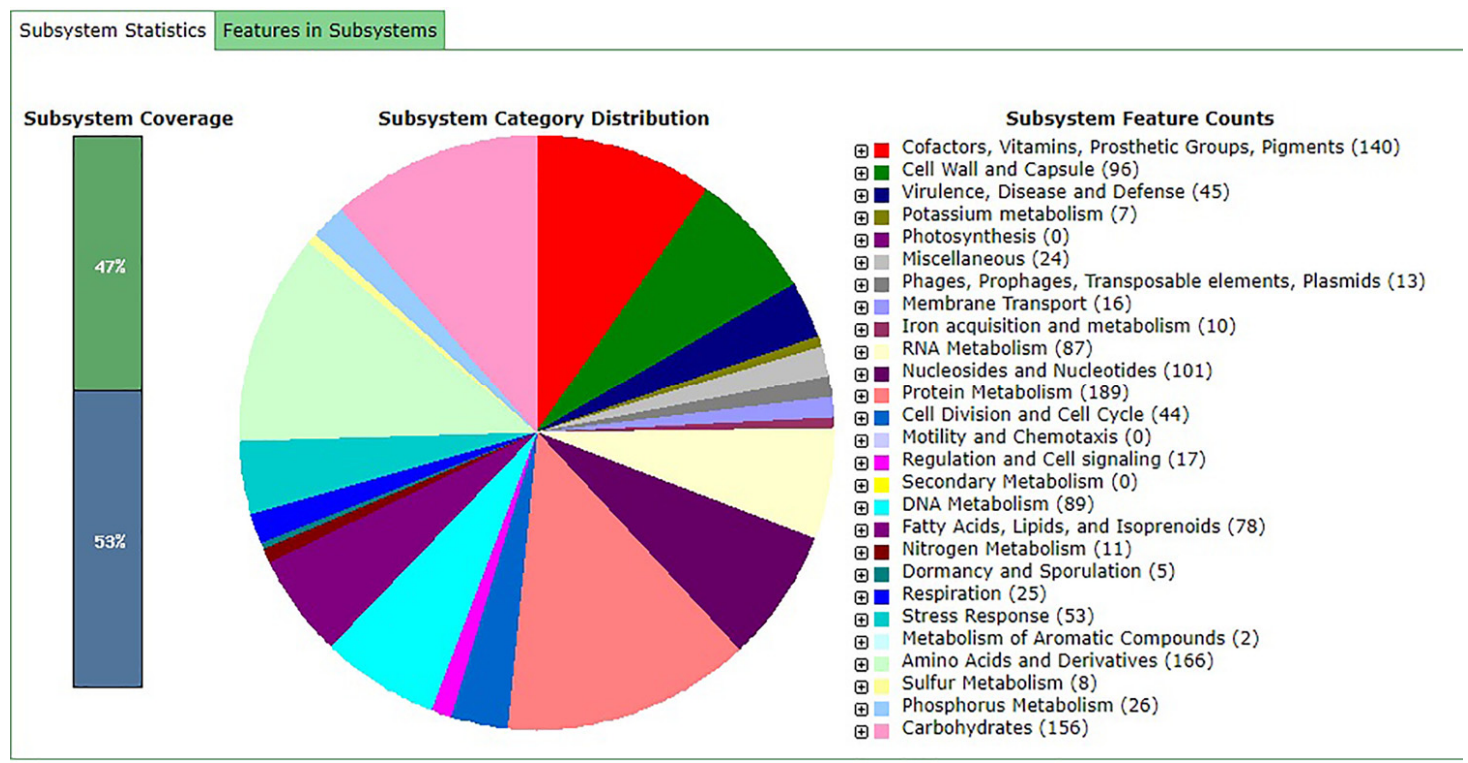

Figure 1. Categories of subsystems of the L. fermentum ATCC 23271 genome annotated by RAST. 
The genome of L. fermentum ATCC 23271 was compared with the whole genomes of other L. fermentum strains in GenBank using the OrthoVenn web platform. The species formed 2183 gene clusters, of which 1262 belonged to at least two species and 921 presented themselves in a single copy. It was also observed that L. fermentum ATCC 23271 shares 941 orthological clusters with all the other tested strains, and that it has 13 exclusive gene clusters (Figure 2).
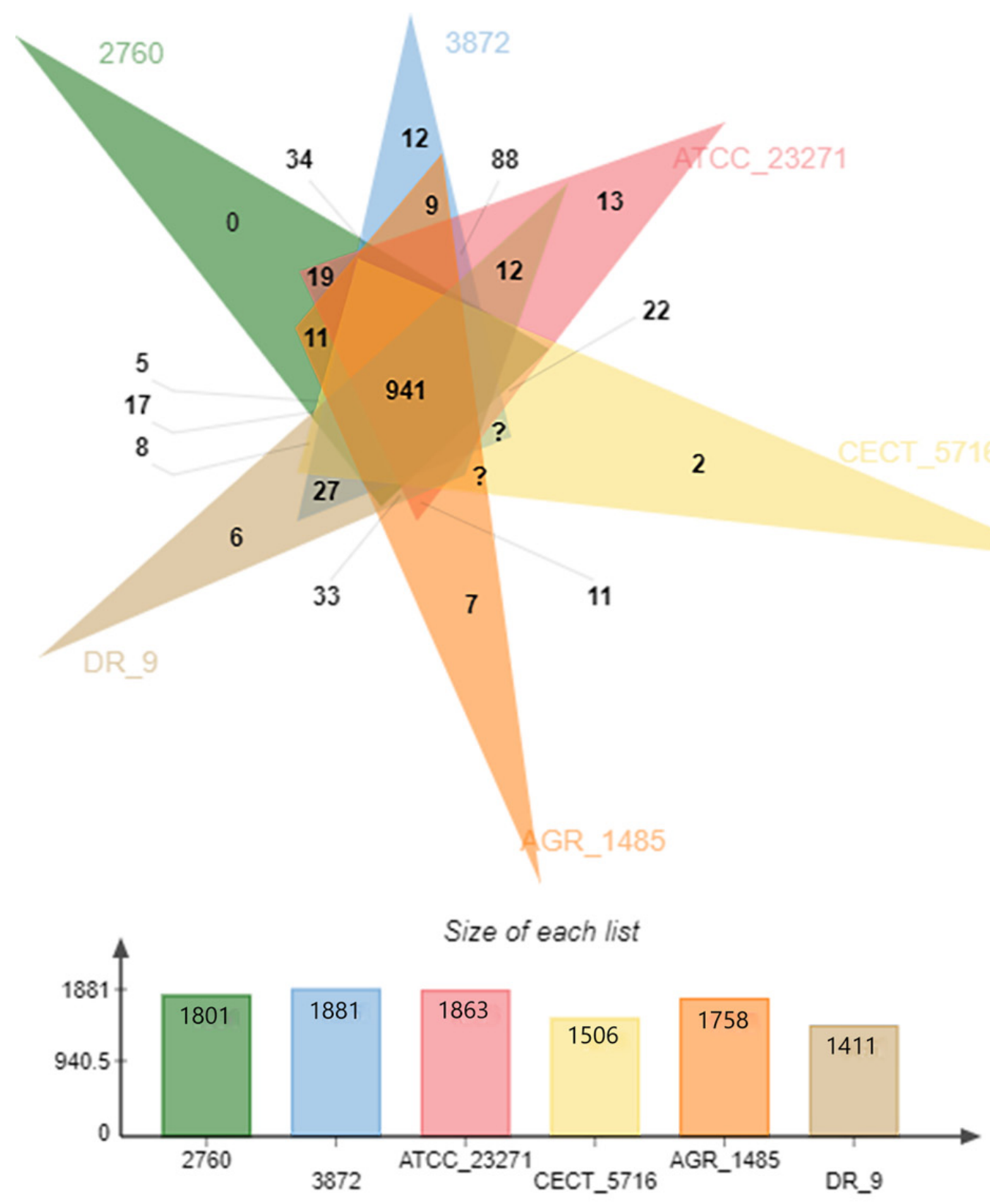

Number of elements: specific (1) or shared by 2, 3,... lists

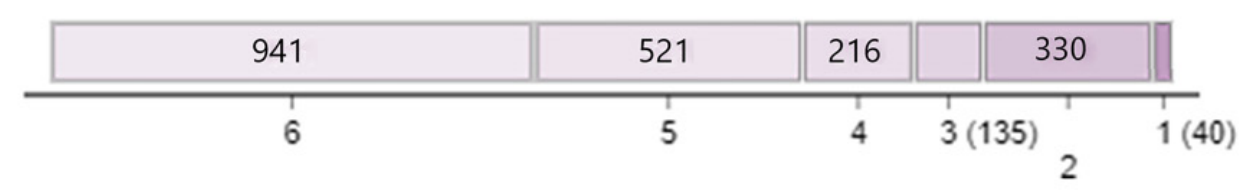

Figure 2. Venn diagram representing the groupings of orthologous genes shared between the following lineages of $L$. fermentum: ATCC 23271, 2760, 3872, CECT 5716, AGR 1485, and DR 9. 
The 941 shared clusters involved a total of 5704 proteins with each strain coding for approximately $16 \%$ of these proteins (Figure 3 ).

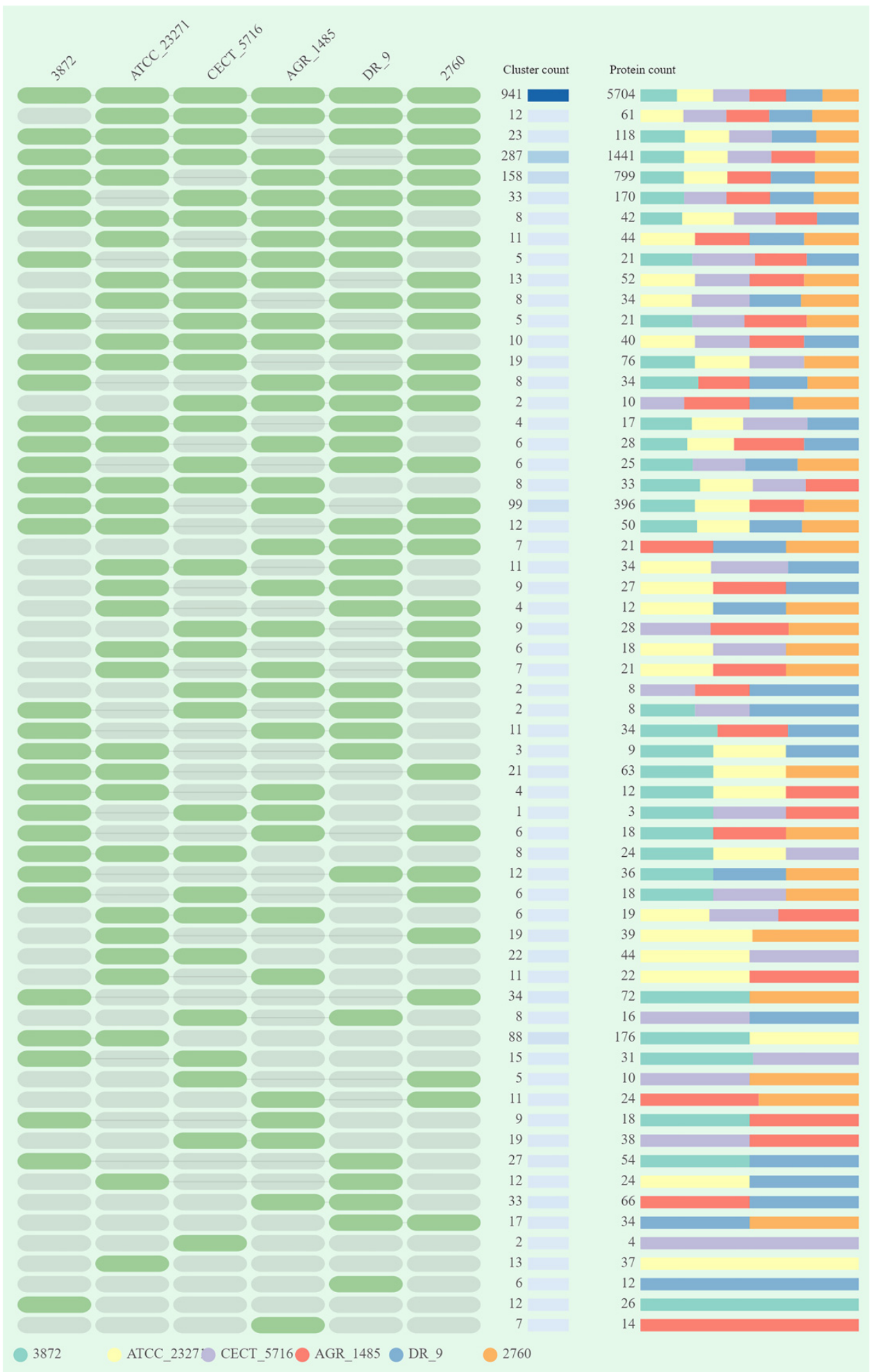

Figure 3. Overlays identified by the OrthoVenn 2 analysis of L. fermentum strains ATCC 23271, 2760, 3872, CECT 5716, AGR 1485 and DR 9. 
Most proteins of these 941 clusters were found to be involved in the biological processes of chemical reactions and their pathways and cell division processes (Figure 4).

With regard to molecular functions, $13.8 \%$ of the identified proteins are involved in hydrolase activity, $12.7 \%$ are related to a biochemical activity or are components of a larger process and $10 \%$ were responsible for the transport of substances inside, outside and between cells (Figure 5).

The third group of proteins is related to the cellular components. In this group, most of the proteins comprised cell compartments (Figure 6).

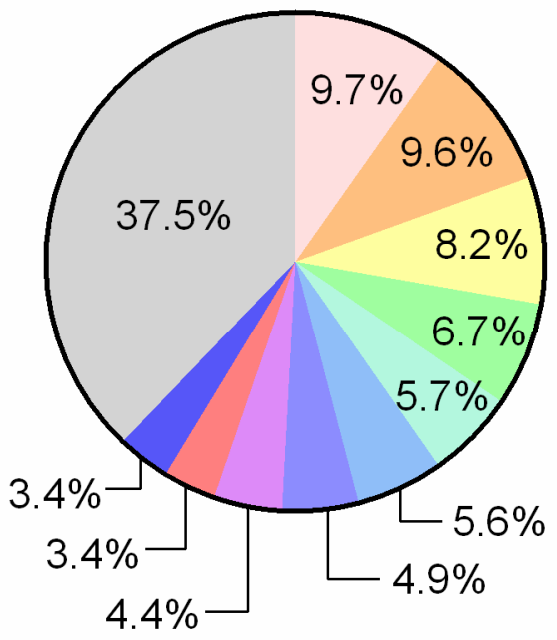

$\square$ metabolic process

$\square$ cell division process

$\square$ cellular metabolic process

$\square$ nitrogen compound metabolic process

$\square$ cellular process

$\square$ primary metabolic process

$\square$ heterocycle metabolic process

$\square$ cellular aromatic compound metabolic process

$\square$ nucleobase-containing compound metabolic process

$\square$ macromolecule metabolic process

$\square$ others

Figure 4. Processes related to proteins belonging to the clusters shared by the L. fermentum strains ATCC 23271, 2760, 3872, CECT 5716, AGR 1485 and DR 9.
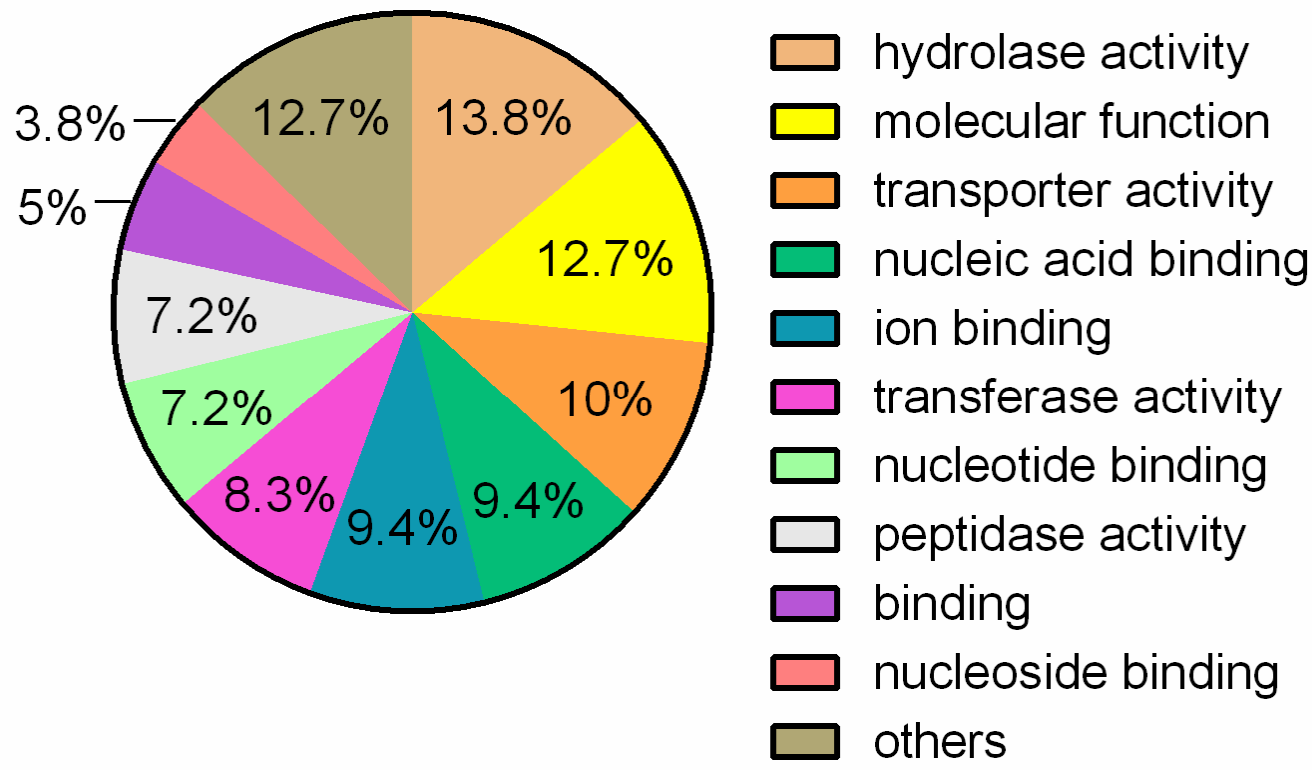

Figure 5. Molecular functions related to proteins belonging to the shared clusters by L. fermentum strains ATCC 23271, 2760, 3872, CECT 5716, AGR 1485 and DR 9. 


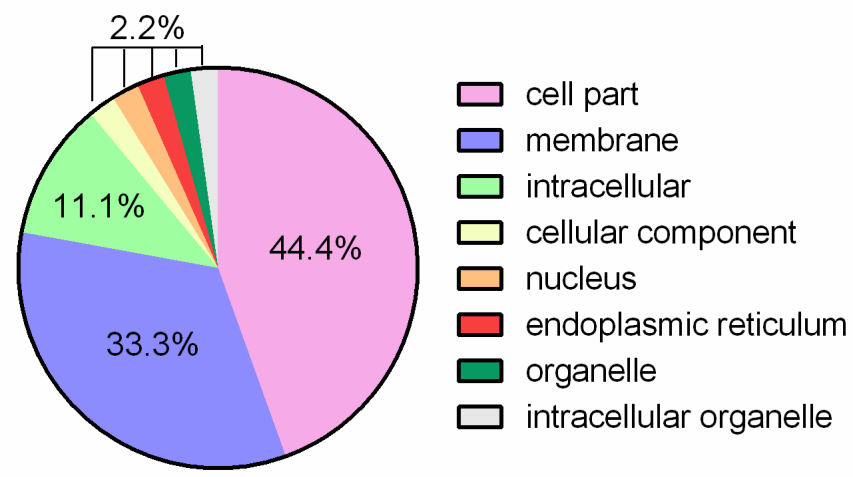

Figure 6. Cell components related to proteins belonging to the shared clusters of L. fermentum strains ATCC 23271, 2760, 3872, CECT 5716, AGR 1485 and DR 9.

Using the reference genomes and other sequences available in the TYGS database, a phylogenetic tree was constructed (Figure 7). Phylogenetic tree analysis showed that the ATCC 23271 strain was the first species to appear during the evolutionary process. Oenococcus alcoholitolerans CBAS 474 was used as the outgroup and, therefore, the most distant on the evolutionary scale among all analyzed species and strains. L. cellobiosus DSM 20055 was also found to be inserted within the clade with other L. fermentum strains. The clade formed by L. fermentum had a 97\% confidence level. L. fermentum ATCC 23271 was found to be more closely related to L. cellobiosus DSM 20055, within the clade, whereas the nearest outside species of the clade was L. gorillae KZ01.
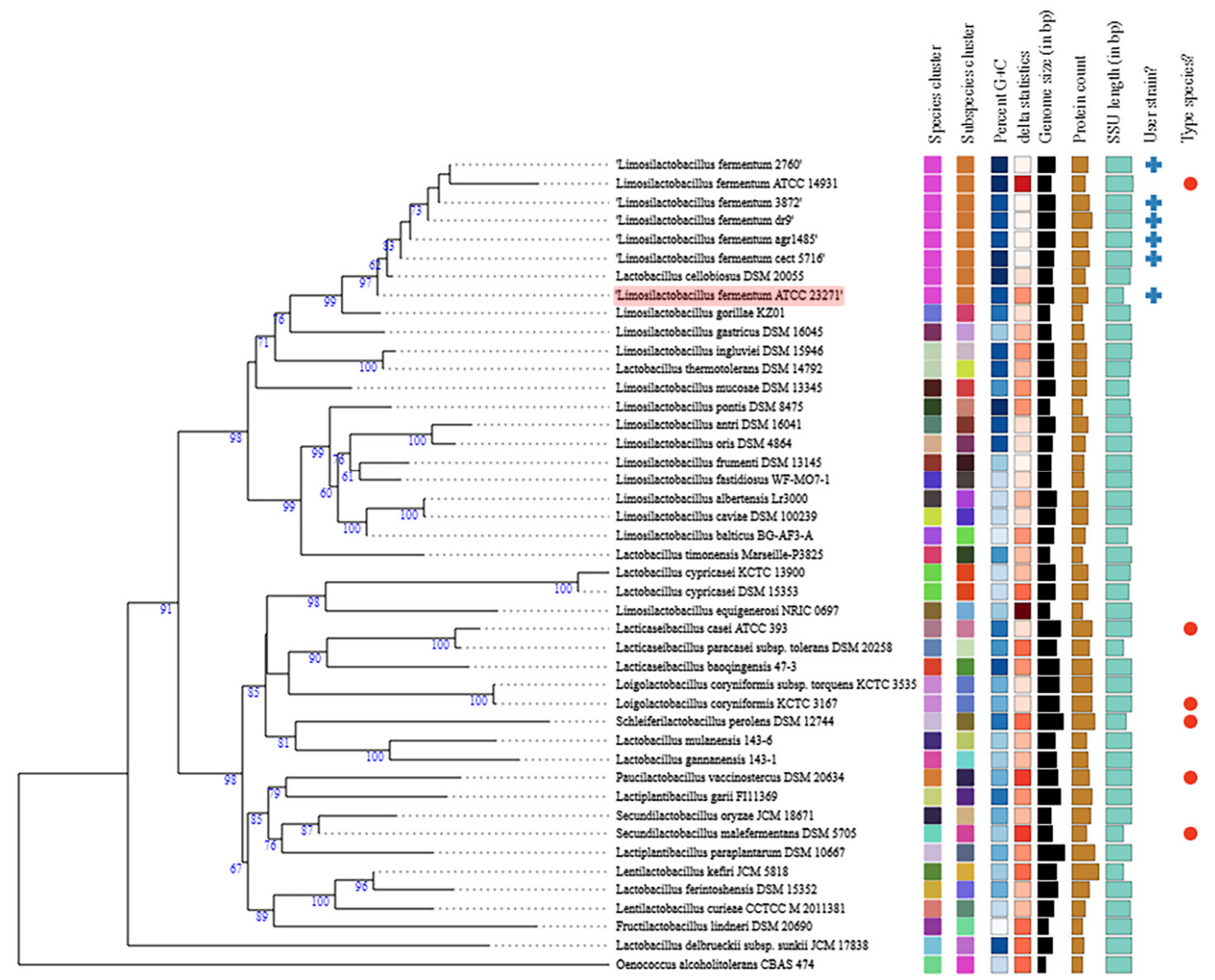

Figure 7. Phylogenetic tree of Limosilactobacillus fermentum ATCC 23271 and other bacterial genera available in the TYGS database. The tree was inferred using FastME 2.1.6.1 from ribosomal DNA. Branch lengths are scaled using the GBDP distance formula d5. The numbers above the branches are GBDP pseudo-bootstrap support values $>60 \%$ of 100 replications, with an average branch support of $19.2 \%$. The tree was rooted at the midpoint. 
Among the 13 exclusive clusters of L. fermentum ATCC 23271, OrthoVenn 2 analysis revealed 37 proteins that were most related to transposition. However, manual analysis showed only 16 ORFs, which included seven encoding transposases and six encoding hypothetical proteins, of which one sequence showed similarity to an L. reuteri hypothetical protein, two sequences that did not show similarity to any described protein and one encoded a chloride transporter, as evidenced by UniProt analysis.

\subsection{Putative Genes Associated with Probiotic Properties}

Genes for the following probiotic features were searched within the genome: tolerance to stress conditions, production of lactic acids, production of adhesion structures, production of antimicrobial peptides and safety for human use. Genomic analysis detected 21 genes encoding proteins that may be related to the ability to tolerate the secretion of digestive enzymes, bile salts and acidic $\mathrm{pH}$. Among them, genes for sugar metabolism and production of L-lactic acid were also present in the genome (Table 2).

Table 2. Genes possibly involved in acid and bile salt tolerance detected in the L. fermentum ATCC 23271 genome.

\begin{tabular}{|c|c|c|c|c|c|c|}
\hline RAST/BLAST Description & $\begin{array}{l}\text { Query } \\
\text { Length }\end{array}$ & $\begin{array}{l}\text { Accession } \\
\text { Length }\end{array}$ & $\begin{array}{l}\text { Query } \\
\text { Cover }\end{array}$ & E Value & $\begin{array}{l}\text { Per } \\
\text { Ident }\end{array}$ & Accession \\
\hline ATP synthase F0 sector subunit a/F0F1 ATP synthase subunit A & $711 \mathrm{pb}$ & 236 aа & $100 \%$ & $7 \times 10^{-167}$ & $100 \%$ & WP_003682740.1 \\
\hline ATP synthase F0 sector subunit b/F0F1 ATP synthase subunit B & $507 \mathrm{pb}$ & 168 aа & $100 \%$ & $6 \times 10^{-116}$ & $100 \%$ & WP_054173734.1 \\
\hline $\begin{array}{c}\text { ATP synthase F0 sector subunit c/MULTISPECIES: F0F1 ATP } \\
\text { synthase subunit C }\end{array}$ & $213 \mathrm{pb}$ & 70 aa & $100 \%$ & $1 \times 10^{-38}$ & $100 \%$ & WP_003682741.1 \\
\hline ATP synthase alpha chain/F0F1 ATP synthase subunit alpha & $1539 \mathrm{pb}$ & 512 aa & $100 \%$ & 0.0 & $99.80 \%$ & WP_086439482.1 \\
\hline ATP synthase beta chain/F0F1 ATP synthase subunit beta & $1422 \mathrm{pb}$ & 473 aа & $100 \%$ & 0.0 & $99.79 \%$ & WP_057194567.1 \\
\hline ATP synthase delta chain/F0F1 ATP synthase subunit delta & $546 \mathrm{pb}$ & 181 aa & $100 \%$ & $3 \times 10^{-126}$ & $99.45 \%$ & WP_057194565.1 \\
\hline $\begin{array}{l}\text { ATP synthase gamma chain/F0F1 ATP synthase subunit } \\
\text { gamma }\end{array}$ & $936 \mathrm{pb}$ & 311 aa & $100 \%$ & 0.0 & $99.68 \%$ & WP_088460387.1 \\
\hline ATP synthase epsilon chain/ & b & 1 & $100 \%$ & $3 \times 10^{-95}$ & 99. & W \\
\hline L-lactate dehydrogenas & 9 & & $\%$ & 0.0 & 99.6 & WP_0 \\
\hline L-lactate dehydrogenase (EC 1.1.1.27)/L-lactate dehydrogenase & $942 \mathrm{bp}$ & 313 aа & $100 \%$ & 0.0 & $100 \%$ & WP_138464682.1 \\
\hline L-lactate dehydrogenase (EC 1.1.1.27)/L-lactate dehydrogenase & $933 \mathrm{bp}$ & 310 aа & $100 \%$ & 0.0 & $100 \%$ & WP_046948611.1 \\
\hline $\begin{array}{l}\text { PTS system, cellobiose-specific IIC component/PTS system } \\
\text { oligo-beta-mannoside-specific EIIC component }\end{array}$ & $1311 \mathrm{bp}$ & 436 aа & $100 \%$ & 0.0 & $100 \%$ & QIX58800.1 \\
\hline $\begin{array}{l}\text { ATP-dependent Clp protease ATP-binding subunit } \\
\text { ClpX/ATP-dependent Clp protease ATP-binding subunit ClpX }\end{array}$ & $1251 \mathrm{bp}$ & 416 aа & $100 \%$ & 0.0 & $99.52 \%$ & WP_096493701.1 \\
\hline $\begin{array}{l}\text { Glucose-6-phosphate isomerase (EC } \\
\text { 5.3.1.9)/glucose-6-phosphate isomerase }\end{array}$ & $525 \mathrm{bp}$ & 174 aa & $100 \%$ & $1 \times 10^{-124}$ & $99.43 \%$ & RGW51862.1 \\
\hline $\begin{array}{l}\text { Glucose-6-phosphate isomerase (EC } \\
\text { 5.3.1.9)/glucose-6-phosphate isomerase }\end{array}$ & $1353 \mathrm{bp}$ & 450 aа & $100 \%$ & 0.0 & $99.56 \%$ & WP_021815746.1 \\
\hline GTP pyrophosphokinase (EC 2.7.6.5)/GTP pyrophosphokinase & 612 & 2 & $100 \%$ & $8 \times 10^{-150}$ & $99.51 \%$ & WP_10C \\
\hline Pyruvate kinase/pyruvate kinase & $1422 \mathrm{bp}$ & 473 & $100 \%$ & 0.0 & $100 \%$ & WP_003684953.1 \\
\hline Arginine/ornithine antiporter ArcD/Amino acid tr & $1419 \mathrm{bp}$ & 472 aа & $100 \%$ & 0.0 & $100 \%$ & AOR74635.1 \\
\hline $\begin{array}{l}\text { Phosphoglycerate mutase/2,3-bisphosphoglycerate-dependent } \\
\text { phosphoglycerate mutase }\end{array}$ & $678 \mathrm{bp}$ & 225 aа & $100 \%$ & $4 \times 10^{-166}$ & $100 \%$ & WP_004562727.1 \\
\hline $\begin{array}{c}\text { Choloylglycine hydrolase/choloylglycine hydrolase family } \\
\text { protein }\end{array}$ & 978 bp & 325 aа & $100 \%$ & 0.0 & $100 \%$ & WP_035436617.1 \\
\hline CTP synthase/CTP synthase & $1602 \mathrm{bp}$ & 533 aа & $100 \%$ & 0.0 & $99.81 \%$ & WP_003684004.1 \\
\hline
\end{tabular}

Eight genes were related to proteins involved in bacterial ability to adhere to and colonize eukaryotic cells, thus competing with pathogenic microorganisms for cell receptors, including: three related to the aggregation process, four related to the production of exopolysaccharides and a fibronectin-binding domain-containing protein (Table 3). 
Table 3. Proteins potentially involved in the adhesion and aggregation properties of L. fermentum ATCC 23271 strain.

\begin{tabular}{|c|c|c|c|c|c|c|c|}
\hline RAST/BLAST Description & Function & $\begin{array}{l}\text { Query } \\
\text { Length }\end{array}$ & $\begin{array}{l}\text { Accession } \\
\text { Length }\end{array}$ & $\begin{array}{l}\text { Query } \\
\text { Cover }\end{array}$ & E Value & $\begin{array}{c}\text { Per } \\
\text { Ident }\end{array}$ & Accession \\
\hline Aggregation substance precursor & \multirow{3}{*}{ Aggregation } & $1842 \mathrm{pb}$ & 613 aа & $99 \%$ & 0.0 & $99.84 \%$ & AKM50933.1 \\
\hline $\begin{array}{l}\text { LysM peptidoglycan-binding } \\
\text { domain-containing protein }\end{array}$ & & $591 \mathrm{pb}$ & 196 aa & $99 \%$ & $9 \times 10^{-85}$ & $100.00 \%$ & WP_021815732.1 \\
\hline $\begin{array}{l}\text { LysM peptidoglycan-binding } \\
\text { domain-containing protein }\end{array}$ & & $816 \mathrm{pb}$ & 315 aа & $48 \%$ & $1 \times 10^{-40}$ & $100.00 \%$ & WP_168183590.1 \\
\hline $\begin{array}{l}\text { Exopolysaccharide biosynthesis polyprenyl } \\
\text { glycosylphosphotransferase }\end{array}$ & \multirow{4}{*}{$\begin{array}{l}\text { Exopolysaccharide } \\
\text { production }\end{array}$} & $666 \mathrm{pb}$ & 229 aа & $99 \%$ & $3 \times 10^{-159}$ & $98.64 \%$ & WP_104877738.1 \\
\hline Exopolysaccharide biosynthesis protein & & $771 \mathrm{pb}$ & 256 aa & $99 \%$ & 0.0 & $99.22 \%$ & WP_163601282.1 \\
\hline CpsD/CapB family tyrosine-protein kinase & & $741 \mathrm{pb}$ & 247 aa & $91 \%$ & $3 \times 10^{-160}$ & $99.12 \%$ & WP_062813522.1 \\
\hline Exopolysaccharide biosynthesis protein & & $771 \mathrm{pb}$ & 256 aа & $99 \%$ & $5 \times 10^{-174}$ & $99.61 \%$ & КРН03198.1 \\
\hline $\begin{array}{l}\text { Fibronectin-binding domain-containing } \\
\text { protein }\end{array}$ & Adhesion & $1692 \mathrm{pb}$ & 563 аа & $99 \%$ & 0.0 & $99.82 \%$ & WP_103205388.1 \\
\hline
\end{tabular}

A search for genes related to the production of bacteriocins was performed using the BAGEL4 program. A sequence $48 \%$ similar to that of enterolysin A, a protein of Enterococcus faecalis, was obtained. Figure 8 shows the position of the bacteriocin sequence in green.

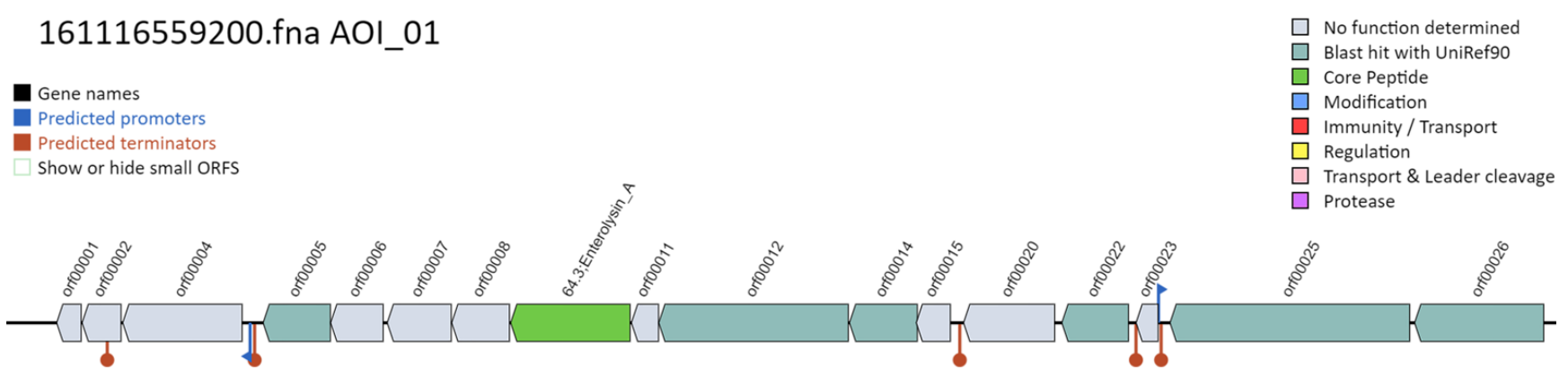

Figure 8. Prediction of a bacteriocin structure in the genome of L. fermentum ATCC 23271 strain.

After identifying the cleavage site of the translated bacteriocin protein sequence, using the SignalP 5.0 server, the mature protein was analyzed in silico to predict its antimicrobial activity by using four algorithms, including Support Vector Machine (SVM), Random Forest (RF), Artificial Neural Network (ANN) and Discriminant Analysis (DA). Of these four algorithms, three indicated a high probability $(>0.9)$ of the peptide to present antimicrobial activity (Table 4).

Table 4. Prediction of antimicrobial activity by using algorithms of $\mathrm{CAMP}_{\mathrm{R} 3}$ database.

\begin{tabular}{cc}
\hline Algorithms * & Results \\
\hline SVM & 1.000 \\
DA & 1.000 \\
RF & 0.957 \\
ANN & NAMP
\end{tabular}

* Support Vector Machine, Discriminant Analysis and Random Forest algorithms report the result as a probability score (0 to 1); the Artificial Neural Network algorithm provides the results as either AMP (antimicrobial) or NAMP (not-antimicrobial).

In the genomic assessment of strain safety, the searches performed in both the ResFinder and CARD databases did not identify any genes encoding acquired drug resistance. However, the L. fermentum ATCC 23271 genome possessed 19 genes related to intrinsic resistance to antibiotics and other toxic compounds, including heavy metals such as cobalt, mercury, cadmium, copper and zinc, or represent potential targets for antimicrobial resistance, such as penicillin-binding protein, elongation factor G, DNA topoisomerase IV subunit B, topoisomerase IV subunit A, DNA topoisomerase (ATP-hydrolyzing) subunit B and DNA gyrase subunit A (Table 5). 
Table 5. Putative genes involved in resistance to antibiotics and toxic compounds.

\begin{tabular}{|c|c|c|c|c|c|c|}
\hline RAST/BLAST Description & $\begin{array}{l}\text { Query } \\
\text { Length }\end{array}$ & $\begin{array}{l}\text { Accession } \\
\text { Length }\end{array}$ & Query Cover & E Value & Per Ident & Accession \\
\hline Penicillin-binding protein & 1017 & 338 & $99 \%$ & 0.0 & $99.41 \%$ & EQC60084.1 \\
\hline $\begin{array}{c}\text { Class A beta-lactamase-related serine } \\
\text { hydrolase }\end{array}$ & 1020 & 339 & $99 \%$ & 0.0 & $99.12 \%$ & MBD9348952.1 \\
\hline $\begin{array}{c}\text { Cation diffusion facilitator family } \\
\text { transporter }\end{array}$ & 906 & 301 & $99 \%$ & 0.0 & $100.00 \%$ & WP_015639412.1 \\
\hline Elongation factor $\mathrm{G}$ & 2085 & 694 & $99 \%$ & 0.0 & $99.86 \%$ & КРH03387.1 \\
\hline DNA topoisomerase IV subunit B & 1998 & 665 & $99 \%$ & 0.0 & $99.85 \%$ & WP_003683141.1 \\
\hline Topoisomerase IV subunit A & 2478 & 825 & $99 \%$ & 0.0 & $100.00 \%$ & BAG27240.1 \\
\hline MerR family transcriptional regulator & 423 & 140 & $99 \%$ & $1 \times 10^{-97}$ & $100.00 \%$ & WP_003682036.1 \\
\hline Multidrug resistance protein MdtG & 342 & 113 & $99 \%$ & $2 \times 10^{-61}$ & $99.12 \%$ & QIX57855.1 \\
\hline MFS transporter & 123 & 160 & $97 \%$ & $2 \times 10^{-17}$ & $97.50 \%$ & WP_155762340.1 \\
\hline GTP-binding protein & 1935 & 644 & $99 \%$ & 0.0 & $100.00 \%$ & WP_112296957.1 \\
\hline Multidrug transporter & 1227 & 413 & $99 \%$ & 0.0 & $99.75 \%$ & AKM51464.1 \\
\hline $\begin{array}{c}\text { DNA topoisomerase } \\
\text { (ATP-hydrolyzing) subunit B }\end{array}$ & 1950 & 649 & $99 \%$ & 0.0 & $99.85 \%$ & WP_023465959.1 \\
\hline DNA gyrase subunit A & 2511 & 836 & $99 \%$ & 0.0 & $99.76 \%$ & WP_160229810.1 \\
\hline MerR family transcriptional regulator & 423 & 151 & $99 \%$ & $3 \times 10^{-98}$ & $100.00 \%$ & CDI69999.1 \\
\hline Multidrug transporter MatE & 1317 & 438 & $99 \%$ & 0.0 & $99.77 \%$ & WP_042513988.1 \\
\hline $\begin{array}{c}\text { Heavy metal translocating P-type } \\
\text { ATPase }\end{array}$ & 1929 & 642 & $99 \%$ & 0.0 & $99.84 \%$ & WP_112297009.1 \\
\hline MATE family efflux transporter & 1320 & 439 & $99 \%$ & 0.0 & $97.95 \%$ & WP_135252410.1 \\
\hline FAD-dependent oxidoreductase & 1350 & 449 & $99 \%$ & 0.0 & $100.00 \%$ & WP_100184414.1 \\
\hline Cation transporter & 552 & 207 & $99 \%$ & $4 \times 10^{-98}$ & $100.00 \%$ & WP_114684362.1 \\
\hline
\end{tabular}

In addition, the strain was predicted to be a non-human pathogen by the PathogenFinder tool hosted by the Centre for Genomic Epidemiology. The probability of being a human pathogen was calculated as 0.202 , indicating a low probability for L. fermentum ATCC 23271 to present pathogenicity, and the estimated matched pathogenic families were 0 . There was no hit for virulence determinants using the VirulenceFinder tool, also hosted by the Centre for Genomic Epidemiology. Two prophage regions were identified within the entire genome, and analysis using the PHASTER tool revealed that the sequences were incomplete. A search for the CRISPR-Cas sequence found two CDS putative sequences for the CRISPR sequences with the associated cas gene. These fragments occurred on contig identity NZ_JAHBRU010000076.1_1 (in the region between 17,626 and 18,783 bp) and NZ_JAHBRU010000115.1_1 (in the region between 850 and 3317 bp). The first identified CRISPR sequence contained 17 spacer genes and a $36 \mathrm{bp}$ repeat consensus (GTCTTGGATGAGTGTCAGATCAGTAGTTCCGAGTAC), and the latter contained 40 spacer genes and a 28 bp repeat consensus (GGATCACCCCCATATACATGGGGAGCAC).

In addition, other putative genes were found in the genome of L. fermentum ATCC 23271 with important features including the following: (i) glutathione biosynthesis bifunctional protein (GshAB) and bifunctional glutamate-cysteine ligase/glutathione synthetase, which are involved in the biosynthesis of glutathione; (ii) peptide methionine sulfoxide reductases (MsrA and MsrB); (iii) free methionine-(R)-sulfoxide reductase; (iv) NADH peroxidase; and (v) thiol peroxidase. These are involved in the bacterial protection against oxidative stress [54-57].

\subsection{Antagonism Activity}

To confirm the inhibitory activity of the ATCC 23271 strain against Candida spp. and its low activity against bacteria [37], the overlay method was used as an antagonism assay. $L$. fermentum ATCC 23271 impaired the growth of Candida spp. with inhibition zones ranging from $13.5 \pm 2.1 \mathrm{~mm}$ to $26.5 \pm 2.1 \mathrm{~mm}$. The only exceptions were two Candida krusei strains (ATCC 6258 and GJFD), which were not inhibited by the probiotic. Regarding the assays with bacterial strains, inhibition was observed only in the area immediately above the growth of the ATCC 23271 strain, that is, without the formation of large inhibition zones (Table 6). 
Table 6. Antagonism assay by the overlay method against L. fermentum ATCC 23271.

\begin{tabular}{cc}
\hline Pathogen & Inhibition Zone in $\mathbf{~ m m ~} \pm$ SD * \\
\hline E. faecalis (ATCC 29212) & In situ \\
E. coli enteroaggregative 17.2 & In situ \\
Salmonella enterica (ATCC 13076) & In situ \\
C. albicans (ATCC 90028) & $17 \pm 1.41$ \\
C. albicans (SC 5314) & $16.5 \pm 1.12$ \\
C. albicans 44 & $14 \pm 1.4$ \\
C. albicans CAS & $20 \pm 0$ \\
C. krusei (ATCC 6258) & - \\
C. krusei GJFD & - \\
Candida parapsilosis (ATCC 22019) & $26.5 \pm 2.1$ \\
C. parapsilosis FSG & $13.5 \pm 2.1$ \\
C. parapsilosis RCL & $14.5 \pm 0.7$ \\
\hline In situ inhibition occurred just above L. fermentum ATCC 23271 growth; - no inhibition.
\end{tabular}

\subsection{Interference in Pathogen Cell Adhesion}

Due to the reduced inhibitory activity of L. fermentum on bacterial pathogens, interference assays on adhesion to HeLa cells were performed only with Candida strains. In the competition assay, three clinical strains (C. albicans CAS, C. krusei GJFD, and C. parapsilosis $\mathrm{RCL}$ ) had their adherence to eukaryotic cells completely inhibited by L. fermentum ATCC 23271, an effect also noted for the reference strain C. parapsilosis ATCC 22019 (Figure 9A). In the exclusion experiment, on one hand, L. fermentum ATCC 23271 decreased the adhesion of C. albicans ATCC 90028, C. krusei ATCC 6258, C. parapsilosis ATCC 22019 and C. parapsilosis FSG to HeLa cells. On the other hand, C. krusei GJFD and C. albicans SC 5314 adhered more in the presence of L. fermentum ATCC 23271 (Figure 9B). In the displacement assay, C. albicans CAS, C. krusei GJFD, C. krusei ATCC 6258 and C. parapsilosis ATCC 22019 showed reduced adhesion to eukaryotic cells (Figure 9C).
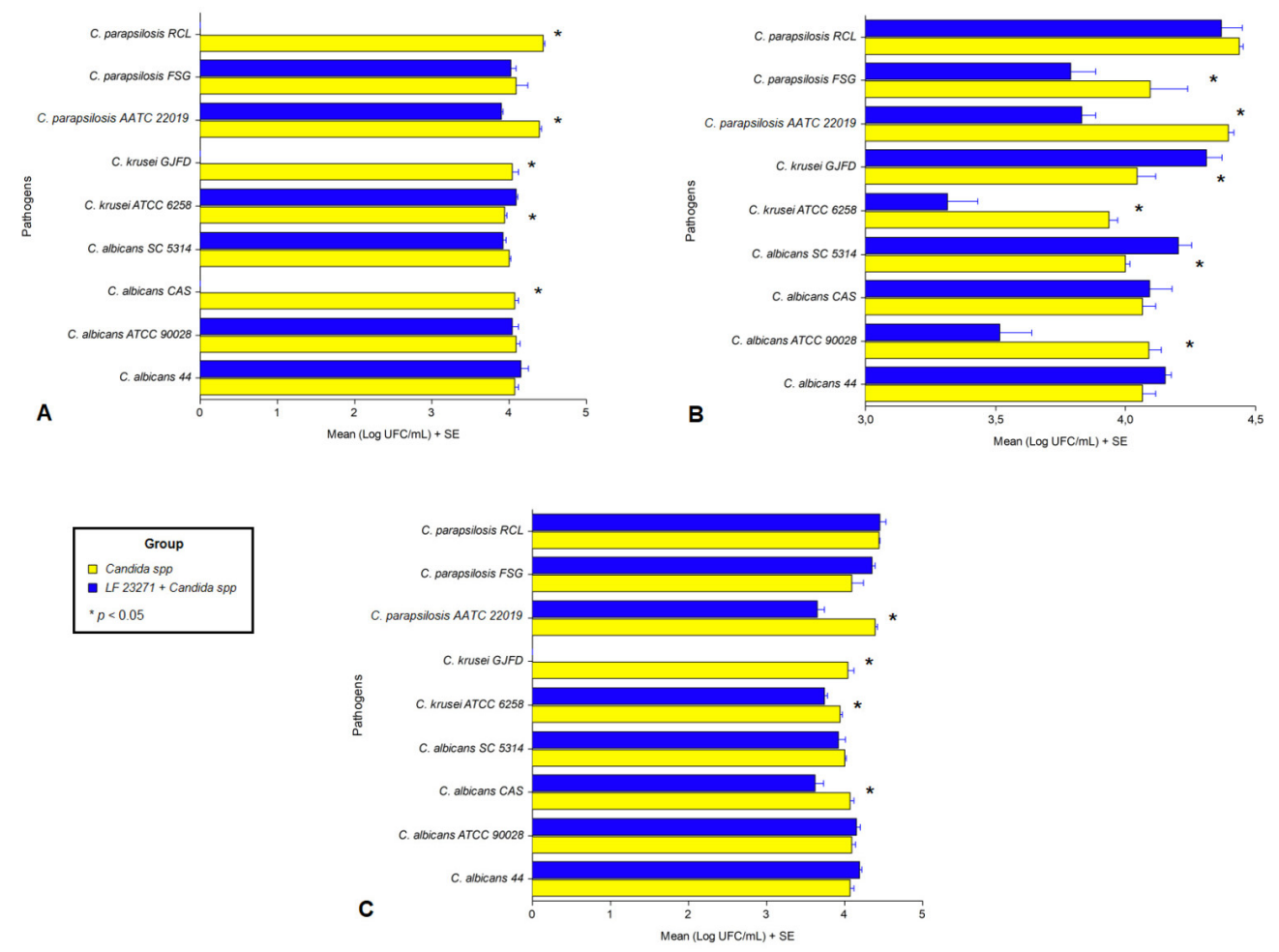

Figure 9. Inhibition of adhesion of Candida strains to eukaryotic cells by L. fermentum ATCC 23271 in three experiments: (A) competition, (B) exclusion and (C) displacement. * Represents the strains that had their adhesion to eukaryotic cells significantly influenced by L. fermentum ATCC 23271. 


\subsection{Tolerance to Bile Salts and Acidic $p H$}

To assess L. fermentum ATCC 23271 resistance to adverse host conditions, the bacterium was incubated in the presence of bile salts and acidic $\mathrm{pH}$. The microorganism demonstrated a higher tolerance when cultivated at $\mathrm{pH} 4.0$; however, it still had a survival rate greater than $60 \%$ when in a more acidic $\mathrm{pH}(\mathrm{pH} 2.0)$. Exposure to bile salts did not affect $L$. fermentum growth. On the contrary, the highest survival rate was found following incubation with $0.5 \%$ bile salts (Table 7 ).

Table 7. L. fermentum ATCC 23271 survival rate in the presence of acidic $\mathrm{pH}$ and bile salts.

\begin{tabular}{|c|c|c|}
\hline Conditions & $\begin{array}{l}\% \text { of L. fermentum Survival } \\
\qquad( \pm \mathrm{SD})^{1}\end{array}$ & $p$-Value ${ }^{2}$ \\
\hline pH 2.0 & $60.88 \pm 0.9569$ & 0.0043 \\
\hline $\mathrm{pH} 4.0$ & $105.0 \pm 5909$ & \\
\hline Bile salt $0.5 \%$ & $109.7 \pm 4434$ & 0.0348 \\
\hline Bile salt $1 \%$ & $94.13 \pm 1244$ & \\
\hline
\end{tabular}

${ }^{1}$ Data represent the survival percentage of L. fermentum ATCC 23271 after 180 min of exposure to different conditions compared to growth under normal conditions. ${ }^{2}$ Statistical analysis was performed by Student's $t$-test $(p<0.05)$.

\subsection{Antibiotic Susceptibility Assay}

Antibiotic susceptibility was assessed by the disc diffusion method. L. fermentum ATCC 23271 was susceptible to most of the tested antibiotics. L. fermentum ATCC 23271 also exhibited moderate susceptibility to cefoxitin and norfloxacin and resistance to gentamycin, trimethoprim/sulfamethoxazole and vancomycin (Table 8).

Table 8. L. fermentum ATCC 23271 antimicrobial susceptibility by the disc diffusion method.

\begin{tabular}{ccc}
\hline Antibiotics & \multicolumn{2}{c}{$\begin{array}{c}\text { L. fermentum ATCC 23271 } \\
\text { Znterpretation * }\end{array}$} \\
\hline Cefazolin & 22 & Susceptible \\
Chloramphenicol & 34 & \\
Ciprofloxacin & 21 & \\
Clindamycin & 31 & \\
Erythromycin & 39 & \\
Linezolid & 40 & \\
Nitrofurantoin & 30 & \\
Rifampicin & 34 & . \\
Penicillin G & 41 & Resistant \\
Tetracycline & 38 & \\
Tigecillin & 40 & \\
Cefoxitin & 15 & \\
Norfloxacin & 14 & \\
Gentamycin & 12 & \\
Sulfazotrim & 0 & \\
Vancomycin & 0 & \\
* Based on the criteria for the diameters of inhibition zones described by Charteris et al. [53].
\end{tabular}

\section{Discussion}

This study presents for the first time, a genomic analysis of L. fermentum ATCC 23271 in regards to important characteristics which confer a strain, a probiotic profile. In addition to its in vitro anti-Candida activity, different in silico functional analyses have revealed several protein-coding sequences associated with other probiotic properties of L. fermentum ATCC 23271, as well as with its safety for human use.

The L. fermentum ATCC 23271 strain was subjected to comparative analysis using the OrthoVenn program with others of the same species, which have previously reported beneficial effects. In this context, L. fermentum CECT 5716 strain has been extensively studied, and its probiotic properties include modulation of the host immune response [58], 
enhanced response to influenza vaccination in adults [59], reduction of Staphylococcus load in breast milk of lactating mothers [60], and reduced incidence of respiratory and gastrointestinal infections in infants [32]. The DR 9 strain has demonstrated antioxidant effects (via upregulation of oxoproline) and immunomodulatory effects in aging rats [61,62]; it also prevents telomere shortening in aging rats [63]. The L. fermentum 3872 strain is known for its potential for combating Campylobacter jejuni infections [30]. This strain also has a unique collagen-binding protein encoded by the $c b p$ gene with five repetitive " $\mathrm{B}$ domains" (whereas the other L. fermentum strains only have four "B domains") [64]. L. fermentum AGR1485 strain has the capacity to increase transepithelial electrical resistance (TEER) across Caco-2 cell layers, thus enhancing barrier integrity and protecting against infections by enteropathogens [65]. L. fermentum MCC 2760 has displayed several activities, including cholesterol reduction, high antioxidant potential, as well as anti-inflammatory actions $[27,66]$. Since L. fermentum ATCC 23271 shares 941 gene clusters with all those strains, it is possible that it also shares some of their probiotic properties.

Phylogenetic analysis showed that L. fermentum ATCC 23271 is part of the clade along with other strains of the same species, including L. cellobiosus DSM 20055. L. cellobiosus was first described by Rogosa et al. [67] and, like L. fermentum, is a heterofermentative Lactobacillus species. Both species share very similar phenotypic properties, and both belong to the subgenus 'Betabacterium' Orla-Jensen of Lactobacillus [68]. These authors support the idea that L. cellobiosus and L. fermentum should be united under the same name, with $L$. fermentum being the earlier synonym [68]. Previous studies have indicated a close relationship between L. cellobiosus and Limosilactobacillus fermentum; in fact, L. cellobiosus has now been reclassified as a biovar of L. fermentum [26]. The external lineage is L. gorillae KZ01, which is phylogenetically related to human-associated L. fermentum; however, it has not been found in humans yet and has been isolated from the feces of a captive western lowland gorilla (Gorilla gorilla) [69].

Concerning the tolerance to adverse conditions, the genome analysis showed that $L$. fermentum ATCC 23271 has several genes encoding proteins that are responsible for the resistance to acidic $\mathrm{pH}$ and bile salts. ATP synthases are some of the proteins involved mainly in acid tolerance, as they are associated with $\mathrm{pH}$ cytoplasmic regulation by ATP hydrolysis, which maintains $\mathrm{pH}$ homeostasis and protects cells from the damage induced by an acidic environment [70]. Glucose-6-phosphate isomerase is also involved in acid tolerance, acting as an acid shock protein [70]. All of these genes and others encoding proteins that promote acid and bile tolerance were detected in the genome of L. fermentum ATCC 23271 [71]. Phenotypic analysis also demonstrated its ability to survive in the presence of acidic $\mathrm{pH}$ and bile salts, corroborating its genetic background. In addition, L. fermentum ATCC 23271 contains putative genes encoding antioxidant enzymes, such as glutathione biosynthesis bifunctional protein, bifunctional glutamate-cysteine ligase, glutathione synthetase, peptide methionine sulfoxide reductases, free methionine-(R)-sulfoxide reductase, $\mathrm{NADH}$ peroxidase and thiol peroxidase. These enzymes (or their products) can protect cells against oxidative damage caused by reactive nitrogen intermediates and reactive oxygen species [55,72,73].

Additionally, other evidence shows that the enzyme methionine sulfoxide reductase (Msr) may also be involved in bacterial adhesion [74]. L. fermentum ATCC23271 has two types of this enzyme (MsrA and MsrB). In this regard, the ability to adhere to host tissues is an important attribute of probiotics [10]. L. fermentum ATCC 23271 presented nine genes encoding adhesion-related proteins, including exopolysaccharides (EPSs), which have different effects on probiotic adhesion to intestinal mucus, according to their different physicochemical and/or structural characteristics [75]. In addition, the gene that encodes the fibronectin-binding protein has also been found, and it is known to facilitate adhesion to the extracellular matrix of mammalian cells [76]. Both mechanisms could enable $L$. fermentum ATCC 23271 to adhere to host tissues and colonize the environment.

Competition for adhesion sites is an additional strategy used by probiotics to inhibit colonization by pathogens. In the present study, a strong ability to inhibit the adhesion of 
some Candida strains to eukaryotic cells was observed (mainly genital clinical isolates) in the competition and displacement assays. Heinemann et al. [77] showed that L. fermentum RC-14 is capable of releasing an active surface component, which can inhibit the adhesion of uropathogenic bacteria. In the same study, it was possible to purify a protein with anti-adhesive capacity against Enterococcus faecalis 1131. Another study showed that $L$. fermentum isolated from humans inhibits the adhesion of enteropathogens, such as that of $E$. coli to host cells, through an SAP protein [78]. The fact that some pathogens present greater adhesion in the presence of L. fermentum ATCC 23271 may be related to the production of aggregation proteins or EPS, as previously suggested $[75,79,80]$.

Bacteriocins are small peptides secreted by many Gram-positive bacteria, with significant activity against distinct microorganisms [81]. A recent study demonstrated that SD11, an L. fermentum-derived bacteriocin, possesses anti-Candida activity [82]. Herein, genomic analysis of L. fermentum ATCC 23271 by the BAGEL 4 program showed the presence of a gene encoding a hypothetical protein with low similarity (48\%) to enterolysin A. Interestingly, this bacteriocin is known to be produced by Enterococcus faecalis LMG 2333 and to inhibit some species of Enterococcus, Lactobacillus, Lactococcus and Pediococcus [83]. We also demonstrated that three algorithms indicated a high probability of this protein with antimicrobial activity. The evidence allows us to suggest that the antifungal activity observed in our study may be due to bacteriocins. However, further studies are necessary to determine the exact bacteriocins or any additional proteins involved in this activity.

Resistance to antibiotics is a concern because of the possibility of transferring the plasmid containing these genes to other pathogenic bacteria, making infections difficult to treat. The European Food Safety Authority (EFSA) recommends that bacterial strains harboring transferable antibiotic resistance genes should not be used as probiotics in animal feeds, fermented foods, and foods for human consumption [84]. Lactobacilli are susceptible to all protein synthesis inhibitors except aminoglycosides but are generally intrinsically resistant to quinolones, trimethoprim and sulphonamides, as well as, in the case of L. fermentum, also to glycopeptides [85]. All antibiotics to which L. fermentum ATCC 23271 showed resistance or moderate susceptibility indicate an intrinsic rather transferable resistance capacity.

L. fermentum ATCC 23271 presented two regions of prophages found in the genome characterized as incomplete, indicating that they were not functional. The identified transposases and other insertion sequences did not flank the resistance genes, further limiting their transferability. Furthermore, genome analysis revealed two regularly intercalated short palindromic repeat sequences (CRISPR) with the Cas gene and associated spacers. It has been reported that the presence of a CRISPR region may limit the spread of antimicrobial-resistant genes by inhibiting gene transfer pathways [86]. The CRISPR-Cas fragments work as a line of defense for the host strain against the insertion of extrachromosomal DNA molecules [50,86]. Therefore, their presence in the strain ATCC 23271 suggests a reduced probability of acquiring antimicrobial-resistant genes.

The protective role of Lactobacillus spp. against Candida spp. has been controversial, as the microorganism can be observed in high amounts in patients with Candida vaginitis [87]. In addition, many women with candidiasis may not have an altered microbiota [88]. These differences may be due to several factors including those inherent to the patient (such as age, immune status and symptoms) and factors related to the virulence properties of the Candida species causing the infection [89]. On the other hand, it has already been clearly demonstrated that a diversity of Lactobacillus spp. has antifungal effects [90-92]. Furthermore, only some strains of Lactobacillus can produce antimicrobial compounds in the amounts necessary for an antifungal activity, which possibly explains the failure of some vaginal lactobacilli to suppress colonization by Candida. In this context, our data indicate that L. fermentum ATCC 23271 may represent a potential strategy to prevent Candida colonization.

Genome sequence analysis can contribute to the understanding of the molecular basis of the probiotic functions of L. fermentum ATCC 23271. However, the genetic basis for 
growth and adhesion inhibitory activities against Candida need to be validated. Thus, gene knockout mutants of this strain are now being constructed to better assess the roles of the putative antimicrobial peptide and adhesin genes in these activities. The most notable feature is the number of genes associated with strain adhesion and survival under unfavorable conditions such as acidic $\mathrm{pH}$, bile salts or even oxidative environments. Other interesting genomic components that represent some of the features that contribute to probiotic activity include many genes involved in sugar transport and metabolism, including oligosaccharides. One element that is part of the general characteristics of a probiotic is its safety for human use, which is assured by the absence of acquired antibiotic resistance and virulence genes, and the presence of gene loci associated with CRISPR/CRISPR (cas) and incomplete prophage regions.

\section{Conclusions}

The data from the present study demonstrate that L. fermentum ATCC 23271 is a probiotic candidate with anti-Candida activity. It can inhibit the growth of C. albicans and C. parapsilosis, in addition to being able to interfere with the adhesion of Candida spp. to host cells. Genomic analyses showed a variety of genes possibly associated with strain adhesion to host cells and molecules, tolerance to acidic $\mathrm{pH}$, bile salts and oxidative stress as well as safety for human consumption. A limitation of the study is that the mechanism of growth inhibition of different Candida species is yet to be completely established. Although we have identified a probable protein with antifungal activity, we still need to validate this finding through studies with mutants, with synthetic peptides (whose sequences are derived from this protein) and also in animal experiments. An important aspect revealed by the comparative genomic analysis is that the strain shares many genes with other strains of the same species that have different probiotic properties. Nonetheless, our findings indicate a promising use of L. fermentum ATCC 23271 as an anti-Candida therapy.

Author Contributions: Conceptualization, C.I.d.S., A.S.M. and V.M.-N.; methodology, C.I.d.S., C.D.L.C., M.S.d.C., F.A.B.N., E.P.S.C., L.F.G., C.R.A.V.M. and V.M.-N.; validation, W.R.N.-N., J.M.M., J.M.M.A., F.S.P. and I.F.S.F.; formal analysis, C.I.d.S., C.R.A.V.M., F.S.P., I.F.S.F., R.A.H., S.G.M., E.S.F., A.S.M. and V.M.-N.; investigation, C.I.d.S., C.D.L.C., M.S.d.C., F.A.B.N., E.P.S.C., L.F.G. and V.M.-N.; data curation, W.R.N.-N., R.M.F., J.M.M., J.M.M.A. and V.M.-N.; writing-original draft preparation, C.I.d.S.; writing-review and editing, F.S.P., I.F.S.F., E.S.F., A.S.M. and V.M.-N.; visualization, C.I.d.S., C.R.A.V.M., R.A.H. and S.G.M.; supervision, V.M.-N.; project administration, C.I.d.S. and V.M.-N.; funding acquisition, S.G.M., E.S.F. and V.M.-N. All authors have read and agreed to the published version of the manuscript.

Funding: This study was financed in part by the Coordenação de Aperfeiçoamento de Pessoal de Nivel Superior-Brazil (CAPES)—Finance Code 001 to E.S.F. and V.M.-N.; Fundação de Amparo à Pesquisa e o Desenvolvimento Científico e Tecnológico do Maranhão (FAPEMA), Universal No. 00995/17 to V.M.-N.; and Conselho Nacional de Desenvolvimento Científico e Tecnológico (CNPQ) grant No. 305676/2019-9 to E.S.F., No. 315348/2020-8 to S.G.M., and No. 315072/2020-2 to V.M.-N.

Institutional Review Board Statement: Not applicable.

Informed Consent Statement: Not applicable.

Data Availability Statement: Sequence data used in this study were deposited at the National Center for Biotechnology Information (NCBI) as part of the BioProject PRJNA729474. Raw reads were deposited in the Sequence Read Archive (SRA) under the accession number SRX10856814. Whole Genome Shotgun assemblies have been deposited at DDBJ/ENA/GenBank under the accession number JAHBRU000000000.1. 
Acknowledgments: The authors would like to thank Hélio Euclides S. dos Santos for technical assistance.

Conflicts of Interest: The authors declare no conflict of interest. The funders had no role in the design of the study; in the collection, analyses, or interpretation of data; in the writing of the manuscript; or in the decision to publish the results.

\section{References}

1. Achkar, J.M.; Fries, B.C. Candida infections of the genitourinary tract. Clin. Microbiol. Rev. 2010, 23, 253-273. [CrossRef]

2. Millsop, J.W.; Fazel, N. Oral candidiasis. Clin. Dermatol. 2016, 34, 487-494. [CrossRef] [PubMed]

3. Sobel, J.D. Vaginitis. N. Engl. J. Med. 1997, 337, 1896-1903. [CrossRef] [PubMed]

4. Pappas, P.G.; Kauffman, C.A.; Andes, D.R.; Clancy, C.J.; Marr, K.A.; Ostrosky-Zeichner, L.; Reboli, A.C.; Schuster, M.G.; Vazquez, J.A.; Walsh, T.J.; et al. Clinical Practice Guideline for the Management of Candidiasis: 2016 Update by the Infectious Diseases Society of America. Clin. Infect. Dis. 2016, 62, e1-e50. [CrossRef]

5. Owen, M.K.; Clenney, T.L. Management of vaginitis. Am. Fam. Phys. 2004, 70, 2125-2132.

6. Mroczynska, M.; Brillowska-Dabrowska, A. Review on Current Status of Echinocandins Use. Antibiotics 2020, 9, 227. [CrossRef]

7. Sobel, J.D.; Sobel, R. Current treatment options for vulvovaginal candidiasis caused by azole-resistant Candida species. Expert Opin. Pharmacother. 2018, 19, 971-977. [CrossRef]

8. Hill, C.; Guarner, F.; Reid, G.; Gibson, G.R.; Merenstein, D.J.; Pot, B.; Morelli, L.; Canani, R.B.; Flint, H.J.; Salminen, S.; et al. Expert consensus document. The International Scientific Association for Probiotics and Prebiotics consensus statement on the scope and appropriate use of the term probiotic. Nat. Rev. Gastroenterol. Hepatol. 2014, 11, 506-514. [CrossRef]

9. Kerry, R.G.; Patra, J.K.; Gouda, S.; Park, Y.; Shin, H.-S.; Das, G. Benefaction of probiotics for human health: A review. J. Food Drug Anal. 2018, 26, 927-939. [CrossRef]

10. do Carmo, M.S.; Santos, C.I.D.; Araujo, M.C.; Giron, J.A.; Fernandes, E.S.; Monteiro-Neto, V. Probiotics, mechanisms of action, and clinical perspectives for diarrhea management in children. Food Func. 2018, 9, 5074-5095. [CrossRef]

11. Johnston, B.C.; Ma, S.S.; Goldenberg, J.Z.; Thorlund, K.; Vandvik, P.O.; Loeb, M.; Guyatt, G.H. Probiotics for the prevention of Clostridium difficile-associated diarrhea: A systematic review and meta-analysis. Ann. Intern. Med. 2012, 157, 878-888. [CrossRef] [PubMed]

12. Feyisetan, O.; Tracey, C.; Hellawell, G.O. Probiotics, dendritic cells and bladder cancer. BJU Int. 2012, 109, 1594-1597. [CrossRef] [PubMed]

13. Hendler, R.; Zhang, Y. Probiotics in the Treatment of Colorectal Cancer. Medicines 2018, 5, 101. [CrossRef] [PubMed]

14. Mendoza, L. Potential effect of probiotics in the treatment of breast cancer. Oncol. Rev. 2019, 13, 422. [CrossRef] [PubMed]

15. Hemarajata, P.; Versalovic, J. Effects of probiotics on gut microbiota: Mechanisms of intestinal immunomodulation and neuromodulation. Ther. Adv. Gastroenterol. 2013, 6, 39-51. [CrossRef]

16. Zimmermann, P.; Curtis, N. The influence of probiotics on vaccine responses-A systematic review. Vaccine 2018, 36, 207-213. [CrossRef]

17. Goderska, K.; Agudo Pena, S.; Alarcon, T. Helicobacter pylori treatment: Antibiotics or probiotics. Appl. Microbiol. Biotechnol. 2018, 102, 1-7. [CrossRef]

18. Moayyedi, P.; Ford, A.C.; Talley, N.J.; Cremonini, F.; Foxx-Orenstein, A.E.; Brandt, L.J.; Quigley, E.M. The efficacy of probiotics in the treatment of irritable bowel syndrome: A systematic review. Gut 2010, 59, 325-332. [CrossRef]

19. Fiocchi, A.; Pawankar, R.; Cuello-Garcia, C.; Ahn, K.; Al-Hammadi, S.; Agarwal, A.; Beyer, K.; Burks, W.; Canonica, G.W.; Ebisawa, M.; et al. World Allergy Organization-McMaster University Guidelines for Allergic Disease Prevention (GLAD-P): Probiotics. World Allergy Organ. J. 2015, 8, 4. [CrossRef]

20. Sargin, P.; Ciecko, A.E.; Dew, K.; Rhonda, G.; Jia, S.; Laib, T.; Roethle, M.F.; Hessner, M.J. Probiotic Supplementation with Lactobacillus plantarum 299v Lowers Systemic Inflammation, Reduces Islet ER Stress and Prevents Type 1 Diabetes in BioBreeding Rats. J. Endocrine Soc. 2021, 5 (Suppl. 1), A661-A662. [CrossRef]

21. Roselli, M.; Pieper, R.; Rogel-Gaillard, C.; de Vries, H.; Bailey, M.; Smidt, H.; Lauridsen, C. Immunomodulating effects of probiotics for microbiota modulation, gut health and disease resistance in pigs. Anim. Feed Sci. Technol. 2017, 233, 104-119. [CrossRef]

22. Rocha-Ramirez, L.M.; Perez-Solano, R.A.; Castanon-Alonso, S.L.; Moreno Guerrero, S.S.; Ramirez Pacheco, A.; Garcia Garibay, M.; Eslava, C. Probiotic Lactobacillus Strains Stimulate the Inflammatory Response and Activate Human Macrophages. J. Immunol. Res. 2017, 2017, 4607491. [CrossRef]

23. Vitetta, L.; Saltzman, E.T.; Thomsen, M.; Nikov, T.; Hall, S. Adjuvant Probiotics and the Intestinal Microbiome: Enhancing Vaccines and Immunotherapy Outcomes. Vaccines 2017, 5, 50. [CrossRef]

24. Hempel, S.; Newberry, S.; Ruelaz, A.; Wang, Z.; Miles, J.; Suttorp, M.J.; Johnsen, B.; Shanman, R.; Slusser, W.; Fu, N. Safety of probiotics used to reduce risk and prevent or treat disease. Evid. Rep./Technol. Assess. 2011, 200, 1-645.

25. Lee, Y.K. Probiotics microorganisms. In Handbook of Probiotics and Prebiotics, 2nd ed.; Lee, Y.K., Salminen, S., Eds.; John Wiley \& Sons: New Jersey, NJ, USA, 2009; pp. 3-24.

26. Zheng, J.; Wittouck, S.; Salvetti, E.; Franz, C.; Harris, H.M.B.; Mattarelli, P.; O’Toole, P.W.; Pot, B.; Vandamme, P.; Walter, J.; et al. A taxonomic note on the genus Lactobacillus: Description of 23 novel genera, emended description of the genus Lactobacillus Beijerinck 1901, and union of Lactobacillaceae and Leuconostocaceae. Int. J. Syst. Evol. Microbiol. 2020, 70, 2782-2858. [CrossRef] 
27. Archer, A.C.; Halami, P.M. Probiotic attributes of Lactobacillus fermentum isolated from human feces and dairy products. Appl. Microbiol. Biotechnol. 2015, 99, 8113-8123. [CrossRef]

28. Cox, A.J.; Pyne, D.B.; Saunders, P.U.; Fricker, P.A. Oral administration of the probiotic Lactobacillus fermentum VRI-003 and mucosal immunity in endurance athletes. Br. J. Sports Med. 2010, 44, 222-226. [CrossRef]

29. Falah, F.; Vasiee, A.; Behbahani, B.A.; Yazdi, F.T.; Moradi, S.; Mortazavi, S.A.; Roshanak, S. Evaluation of adherence and antiinfective properties of probiotic Lactobacillus fermentum strain 4-17 against Escherichia coli causing urinary tract infection in humans. Microb. Pathog. 2019, 131, 246-253. [CrossRef]

30. Lehri, B.; Seddon, A.; Karlyshev, A. Lactobacillus fermentum 3872 as a potential tool for combatting Campylobacter jejuni infections. Virulence 2017, 8, 1753-1760. [CrossRef]

31. Lin, W.H.; Yu, B.; Jang, S.H.; Tsen, H.Y. Different probiotic properties for Lactobacillus fermentum strains isolated from swine and poultry. Anaerobe 2007, 13, 107-113. [CrossRef]

32. Maldonado, J.; Canabate, F.; Sempere, L.; Vela, F.; Sanchez, A.R.; Narbona, E.; Lopez-Huertas, E.; Geerlings, A.; Valero, A.D.; Olivares, M.; et al. Human milk probiotic Lactobacillus fermentum CECT5716 reduces the incidence of gastrointestinal and upper respiratory tract infections in infants. J. Pediatr. Gastroenterol. Nutr. 2012, 54, 55-61. [CrossRef]

33. Mikelsaar, M.; Zilmer, M. Lactobacillus fermentum ME-3-An antimicrobial and antioxidative probiotic. Microb. Ecol. Health Dis. 2009, 21, 1-27. [CrossRef] [PubMed]

34. Ramos, C.L.; Thorsen, L.; Schwan, R.F.; Jespersen, L. Strain-specific probiotics properties of Lactobacillus fermentum, Lactobacillus plantarum and Lactobacillus brevis isolates from Brazilian food products. Food Microbiol. 2013, 36, 22-29. [CrossRef]

35. Pereira, D.I.; McCartney, A.L.; Gibson, G.R. An in vitro study of the probiotic potential of a bile-salt-hydrolyzing Lactobacillus fermentum strain, and determination of its cholesterol-lowering properties. Appl. Environ. Microbiol. 2003, 69, 4743-4752. [CrossRef]

36. Zhao, Y.; Hong, K.; Zhao, J.; Zhang, H.; Zhai, Q.; Chen, W. Lactobacillus fermentum and its potential immunomodulatory properties. J. Funct. Foods 2019, 56, 21-32. [CrossRef]

37. do Carmo, M.S.; Noronha, F.M.; Arruda, M.O.; Costa, E.P.; Bomfim, M.R.; Monteiro, A.S.; Ferro, T.A.; Fernandes, E.S.; Giron, J.A.; Monteiro-Neto, V. Lactobacillus fermentum ATCC 23271 Displays In vitro Inhibitory Activities against Candida spp. Front. Microbiol. 2016, 7, 1722. [CrossRef]

38. Coil, D.; Jospin, G.; Darling, A.E. A5-miseq: An updated pipeline to assemble microbial genomes from Illumina MiSeq data. Bioinformatics 2015, 31, 587-589. [CrossRef] [PubMed]

39. Huang, X.; Madan, A. CAP3: A DNA sequence assembly program. Genome Res. 1999, 9, 868-877. [CrossRef]

40. Seemann, T. Prokka: Rapid prokaryotic genome annotation. Bioinformatics 2014, 30, 2068-2069. [CrossRef]

41. Wang, Y.; Coleman-Derr, D.; Chen, G.; Gu, Y.Q. OrthoVenn: A web server for genome wide comparison and annotation of orthologous clusters across multiple species. Nucleic Acids Res. 2015, 43, W78-W84. [CrossRef]

42. Almagro Armenteros, J.J.; Tsirigos, K.D.; Sonderby, C.K.; Petersen, T.N.; Winther, O.; Brunak, S.; von Heijne, G.; Nielsen, H. SignalP 5.0 improves signal peptide predictions using deep neural networks. Nat. Biotechnol. 2019, 37, 420-423. [CrossRef]

43. Meier-Kolthoff, J.P.; Göker, M. TYGS is an automated high-throughput platform for state-of-the-art genome-based taxonomy. Nat. Commun. 2019, 10, 2182. [CrossRef]

44. Darling, A.E.; Mau, B.; Perna, N.T. progressiveMauve: Multiple genome alignment with gene gain, loss and rearrangement. PLoS ONE 2010, 5, e11147. [CrossRef] [PubMed]

45. Cosentino, S.; Voldby Larsen, M.; Møller Aarestrup, F.; Lund, O. PathogenFinder-distinguishing friend from foe using bacterial whole genome sequence data. PLoS ONE 2013, 8, e77302. [CrossRef]

46. Zankari, E.; Hasman, H.; Cosentino, S.; Vestergaard, M.; Rasmussen, S.; Lund, O.; Aarestrup, F.M.; Larsen, M.V. Identification of acquired antimicrobial resistance genes. J. Antimicrob. Chemother. 2012, 67, 2640-2644. [CrossRef] [PubMed]

47. Alcock, B.P.; Raphenya, A.R.; Lau, T.T.Y.; Tsang, K.K.; Bouchard, M.; Edalatmand, A.; Huynh, W.; Nguyen, A.V.; Cheng, A.A.; Liu, S.; et al. CARD 2020: Antibiotic resistome surveillance with the comprehensive antibiotic resistance database. Nucleic Acids Res. 2020, 48, D517-D525. [CrossRef] [PubMed]

48. Joensen, K.G.; Scheutz, F.; Lund, O.; Hasman, H.; Kaas, R.S.; Nielsen, E.M.; Aarestrup, F.M. Real-time whole-genome sequencing for routine typing, surveillance, and outbreak detection of verotoxigenic Escherichia coli. J. Clin. Microbiol. 2014, 52, 1501-1510. [CrossRef]

49. Arndt, D.; Grant, J.R.; Marcu, A.; Sajed, T.; Pon, A.; Liang, Y.; Wishart, D.S. PHASTER: A better, faster version of the PHAST phage search tool. Nucleic Acids Res. 2016, 44, W16-W21. [CrossRef]

50. Grissa, I.; Vergnaud, G.; Pourcel, C. CRISPRFinder: A web tool to identify clustered regularly interspaced short palindromic repeats. Nucleic Acids Res. 2007, 35, W52-W57. [CrossRef]

51. Kaewnopparat, S.; Dangmanee, N.; Kaewnopparat, N.; Srichana, T.; Chulasiri, M.; Settharaksa, S. In vitro probiotic properties of Lactobacillus fermentum SK5 isolated from vagina of a healthy woman. Anaerobe 2013, 22, 6-13. [CrossRef] [PubMed]

52. Monteiro, C.; do Carmo, M.S.; Melo, B.O.; Alves, M.S.; Dos Santos, C.I.; Monteiro, S.G.; Bomfim, M.R.Q.; Fernandes, E.S.; Monteiro-Neto, V. In Vitro Antimicrobial Activity and Probiotic Potential of Bifidobacterium and Lactobacillus against Species of Clostridium. Nutrients 2019, 11, 448. [CrossRef]

53. Charteris, W.P.; Kelly, P.M.; Morelli, L.; Collins, J.K. Antibiotic susceptibility of potentially probiotic Lactobacillus species. J. Food Prot. 1998, 61, 1636-1643. [CrossRef] 
54. Al-Madboly, L.A.; Khedr, E.G.; Ali, S.M. Optimization of Reduced Glutathione Production by a Lactobacillus plantarum Isolate Using Plackett-Burman and Box-Behnken Designs. Front. Microbiol. 2017, 8, 772. [CrossRef]

55. Ianniello, R.G.; Zheng, J.; Zotta, T.; Ricciardi, A.; Ganzle, M.G. Biochemical analysis of respiratory metabolism in the heterofermentative Lactobacillus spicheri and Lactobacillus reuteri. J. Appl. Microbiol. 2015, 119, 763-775. [CrossRef]

56. Walter, J.; Heng, N.C.; Hammes, W.P.; Loach, D.M.; Tannock, G.W.; Hertel, C. Identification of Lactobacillus reuteri genes specifically induced in the mouse gastrointestinal tract. Appl. Environ. Microbiol. 2003, 69, 2044-2051. [CrossRef]

57. Zhang, W.; Ji, H.; Zhang, D.; Liu, H.; Wang, S.; Wang, J.; Wang, Y. Complete Genome Sequencing of Lactobacillus plantarum ZLP001, a Potential Probiotic That Enhances Intestinal Epithelial Barrier Function and Defense Against Pathogens in Pigs. Front. Physiol. 2018, 9, 1689. [CrossRef]

58. Martínez-Abad, B.; Garrote, J.A.; Bernardo, D.; Montalvillo, E.; Escudero-Hernández, C.; Vázquez, E.; Rueda, R.; Arranz, E. Differential immunomodulatory effects of Lactobacillus rhamnosus DR20, Lactobacillus fermentum CECT 5716 and Bifidobacterium animalis subsp. lactis on monocyte-derived dendritic cells. J. Funct. Foods 2016, 22, 300-312. [CrossRef]

59. Olivares, M.; Diaz-Ropero, M.P.; Sierra, S.; Lara-Villoslada, F.; Fonolla, J.; Navas, M.; Rodriguez, J.M.; Xaus, J. Oral intake of Lactobacillus fermentum CECT5716 enhances the effects of influenza vaccination. Nutrition 2007, 23, 254-260. [CrossRef]

60. Maldonado-Lobon, J.A.; Diaz-Lopez, M.A.; Carputo, R.; Duarte, P.; Diaz-Ropero, M.P.; Valero, A.D.; Sanudo, A.; Sempere, L.; Ruiz-Lopez, M.D.; Banuelos, O.; et al. Lactobacillus fermentum CECT 5716 Reduces Staphylococcus Load in the Breastmilk of Lactating Mothers Suffering Breast Pain: A Randomized Controlled Trial. Breastfeed. Med. 2015, 10, 425-432. [CrossRef]

61. Hor, Y.Y.; Lew, L.C.; Jaafar, M.H.; Lau, A.S.; Ong, J.S.; Kato, T.; Nakanishi, Y.; Azzam, G.; Azlan, A.; Ohno, H.; et al. Lactobacillus sp. improved microbiota and metabolite profiles of aging rats. Pharmacol. Res. 2019, 146, 104312. [CrossRef]

62. Hor, Y.Y.; Ooi, C.H.; Lew, L.C.; Jaafar, M.H.; Lau, A.S.; Lee, B.K.; Azlan, A.; Choi, S.B.; Azzam, G.; Liong, M.T. The molecular mechanisms of probiotic strains in improving ageing bone and muscle of d-galactose-induced ageing rats. J. Appl. Microbiol. 2021, 130, 1307-1322. [CrossRef] [PubMed]

63. Lew, L.C.; Hor, Y.Y.; Jaafar, M.H.; Lau, A.S.Y.; Ong, J.S.; Chuah, L.O.; Yap, K.P.; Azzam, G.; Azlan, A.; Liong, M.T. Lactobacilli modulated AMPK activity and prevented telomere shortening in ageing rats. Benef. Microbes 2019, 10, 883-892. [CrossRef] [PubMed]

64. Lehri, B.; Seddon, A.; Karlyshev, A. Discovery and characterisation of a novel plasmid of a probiotic strain Lactobacillus fermentum 3872. In Proceedings of the International Conference on Antimicrobial Research, Madrid, Spain, 1-3 October 2014.

65. Anderson, R.C.; Cookson, A.L.; McNabb, W.C.; Kelly, W.J.; Roy, N.C. Lactobacillus plantarum DSM 2648 is a potential probiotic that enhances intestinal barrier function. FEMS Microbiol. Lett. 2010, 309, 184-192. [CrossRef]

66. Archer, A.C.; Kurrey, N.K.; Halami, P.M. In vitro adhesion and anti-inflammatory properties of native Lactobacillus fermentum and Lactobacillus delbrueckii spp. J. Appl. Microbiol. 2018, 125, 243-256. [CrossRef]

67. Rogosa, M.; Wiseman, R.; Mitchell, J.A.; Disraely, M.; Beaman, A. Species differentiation of oral lactobacilli from man including descriptions of Lactobacillus salivarius nov spec and Lactobacillus cellobiosus nov spec. J. Bacteriol. 1953, 65, 681-699. [CrossRef]

68. Dellaglio, F.; Torriani, S.; Felis, G.E. Reclassification of Lactobacillus cellobiosus Rogosa et al. 1953 as a later synonym of Lactobacillus fermentum Beijerinck 1901. Int. J. Syst. Evol. Microbiol. 2004, 54, 809-812. [CrossRef]

69. Tsuchida, S.; Nezuo, M.; Tsukahara, M.; Ogura, Y.; Hayashi, T.; Ushida, K. Draft Genome Sequence of Lactobacillus gorillae Strain KZ01T, Isolated from a Western Lowland Gorilla. Genome Announc. 2015, 3, e01196-15. [CrossRef]

70. Oliveira, L.C.; Saraiva, T.D.; Silva, W.M.; Pereira, U.P.; Campos, B.C.; Benevides, L.J.; Rocha, F.S.; Figueiredo, H.C.; Azevedo, V.; Soares, S.C. Analyses of the probiotic property and stress resistance-related genes of Lactococcus lactis subsp. lactis NCDO 2118 through comparative genomics and in vitro assays. PLoS ONE 2017, 12, e0175116. [CrossRef]

71. Jayashree, S.; Pooja, S.; Pushpanathan, M.; Rajendhran, J.; Gunasekaran, P. Identification and characterization of bile salt hydrolase genes from the genome of Lactobacillus fermentum MTCC 8711. Appl. Biochem. Biotechnol. 2014, 174, 855-866. [CrossRef]

72. John, G.S.; Brot, N.; Ruan, J.; Erdjument-Bromage, H.; Tempst, P.; Weissbach, H.; Nathan, C. Peptide methionine sulfoxide reductase from Escherichia coli and Mycobacterium tuberculosis protects bacteria against oxidative damage from reactive nitrogen intermediates. Proc. Natl. Acad. Sci. USA 2001, 98, 9901-9906. [CrossRef]

73. Skaar, E.P.; Tobiason, D.M.; Quick, J.; Judd, R.C.; Weissbach, H.; Etienne, F.; Brot, N.; Seifert, H.S. The outer membrane localization of the Neisseria gonorrhoeae MsrA/B is involved in survival against reactive oxygen species. Proc. Natl. Acad. Sci. USA 2002, 99, 10108-10113. [CrossRef]

74. Brot, N.; Weissbach, H. Peptide methionine sulfoxide reductase: Biochemistry and physiological role. Biopolymers 2000, 55, 288-296. [CrossRef]

75. Ruas-Madiedo, P.; Gueimonde, M.; Margolles, A.; de los Reyes-Gavilan, C.G.; Salminen, S. Exopolysaccharides produced by probiotic strains modify the adhesion of probiotics and enteropathogens to human intestinal mucus. J. Food Prot. 2006, 69, 2011-2015. [CrossRef] [PubMed]

76. Kapse, N.G.; Engineer, A.S.; Gowdaman, V.; Wagh, S.; Dhakephalkar, P.K. Functional annotation of the genome unravels probiotic potential of Bacillus coagulans HS243. Genomics 2019, 111, 921-929. [CrossRef]

77. Heinemann, C.; van Hylckama Vlieg, J.E.; Janssen, D.B.; Busscher, H.J.; van der Mei, H.C.; Reid, G. Purification and characterization of a surface-binding protein from Lactobacillus fermentum RC-14 that inhibits adhesion of Enterococcus faecalis 1131. FEMS Microbiol. Lett. 2000, 190, 177-180. [CrossRef] 
78. Varma, P.; Dinesh, K.R.; Menon, K.K.; Biswas, R. Lactobacillus fermentum isolated from human colonic mucosal biopsy inhibits the growth and adhesion of enteric and foodborne pathogens. J. Food Sci. 2010, 75, M546-M551. [CrossRef]

79. Marcotte, H.; Ferrari, S.; Cesena, C.; Hammarstrom, L.; Morelli, L.; Pozzi, G.; Oggioni, M.R. The aggregation-promoting factor of Lactobacillus crispatus M247 and its genetic locus. J. Appl. Microbiol. 2004, 97, 749-756. [CrossRef]

80. Martín, R.; Sánchez, B.; Suárez, J.E.; Urdaci, M.C. Characterization of the adherence properties of human Lactobacilli strains to be used as vaginal probiotics. FEMS Microbiol. Lett. 2012, 328, 166-173. [CrossRef]

81. Cotter, P.D.; Ross, R.P.; Hill, C. Bacteriocins-A viable alternative to antibiotics? Nat. Rev. Microbiol. 2013, 11, 95-105. [CrossRef]

82. Wannun, P.; Piwat, S.; Teanpaisan, R. Purification, Characterization, and Optimum Conditions of Fermencin SD11, a Bacteriocin Produced by Human Orally Lactobacillus fermentum SD11. Appl. Biochem. Biotechnol. 2016, 179, 572-582. [CrossRef]

83. Nilsen, T.; Nes, I.F.; Holo, H. Enterolysin A, a cell wall-degrading bacteriocin from Enterococcus faecalis LMG 2333. Appl. Environ. Microbiol. 2003, 69, 2975-2984. [CrossRef]

84. European Food Safety Authority (EFSA). Introduction of a Qualified Presumption of Safety (QPS) approach for assessment of selected microorganisms referred to EFSA-Opinion of the Scientific Committee. EFSA J. 2007, 5, 587. [CrossRef]

85. Nawaz, M.; Wang, J.; Zhou, A.; Ma, C.; Wu, X.; Moore, J.E.; Millar, B.C.; Xu, J. Characterization and transfer of antibiotic resistance in lactic acid bacteria from fermented food products. Curr. Microbiol. 2011, 62, 1081-1089. [CrossRef]

86. Palmer, K.L.; Gilmore, M.S. Multidrug-resistant enterococci lack CRISPR-cas. mBio 2010, 1, e00227-e00310. [CrossRef] [PubMed]

87. McClelland, R.S.; Richardson, B.A.; Hassan, W.M.; Graham, S.M.; Kiarie, J.; Baeten, J.M.; Mandaliya, K.; Jaoko, W.; Ndinya-Achola, J.O.; Holmes, K.K. Prospective study of vaginal bacterial flora and other risk factors for vulvovaginal candidiasis. J. Infect. Dis. 2009, 199, 1883-1890. [CrossRef]

88. Pramanick, R.; Mayadeo, N.; Warke, H.; Begum, S.; Aich, P.; Aranha, C. Vaginal microbiota of asymptomatic bacterial vaginosis and vulvovaginal candidiasis: Are they different from normal microbiota? Microb. Pathog. 2019, 134, 103599. [CrossRef] [PubMed]

89. Willems, H.M.E.; Ahmed, S.S.; Liu, J.; Xu, Z.; Peters, B.M. Vulvovaginal Candidiasis: A Current Understanding and Burning Questions. J. Fungi 2020, 6, 27. [CrossRef] [PubMed]

90. Fuochi, V.; Cardile, V.; Petronio Petronio, G.; Furneri, P.M. Biological properties and production of bacteriocins-like-inhibitory substances by Lactobacillus sp. strains from human vagina. J. Appl. Microbiol. 2019, 126, 1541-1550. [CrossRef]

91. Itapary Dos Santos, C.; Ramos Franca, Y.; Duarte Lima Campos, C.; Quaresma Bomfim, M.R.; Oliveira Melo, B.; Assuncao Holanda, R.; Santos, V.L.; Gomes Monteiro, S.; Buozzi Moffa, E.; Souza Monteiro, A.; et al. Antifungal and Antivirulence Activity of Vaginal Lactobacillus Spp. Products against Candida Vaginal Isolates. Pathogens 2019, 8, 150. [CrossRef]

92. Wang, S.; Wang, Q.; Yang, E.; Yan, L.; Li, T.; Zhuang, H. Antimicrobial Compounds Produced by Vaginal Lactobacillus crispatus Are Able to Strongly Inhibit Candida albicans Growth, Hyphal Formation and Regulate Virulence-related Gene Expressions. Front. Microbiol. 2017, 8, 564. [CrossRef] [PubMed] 